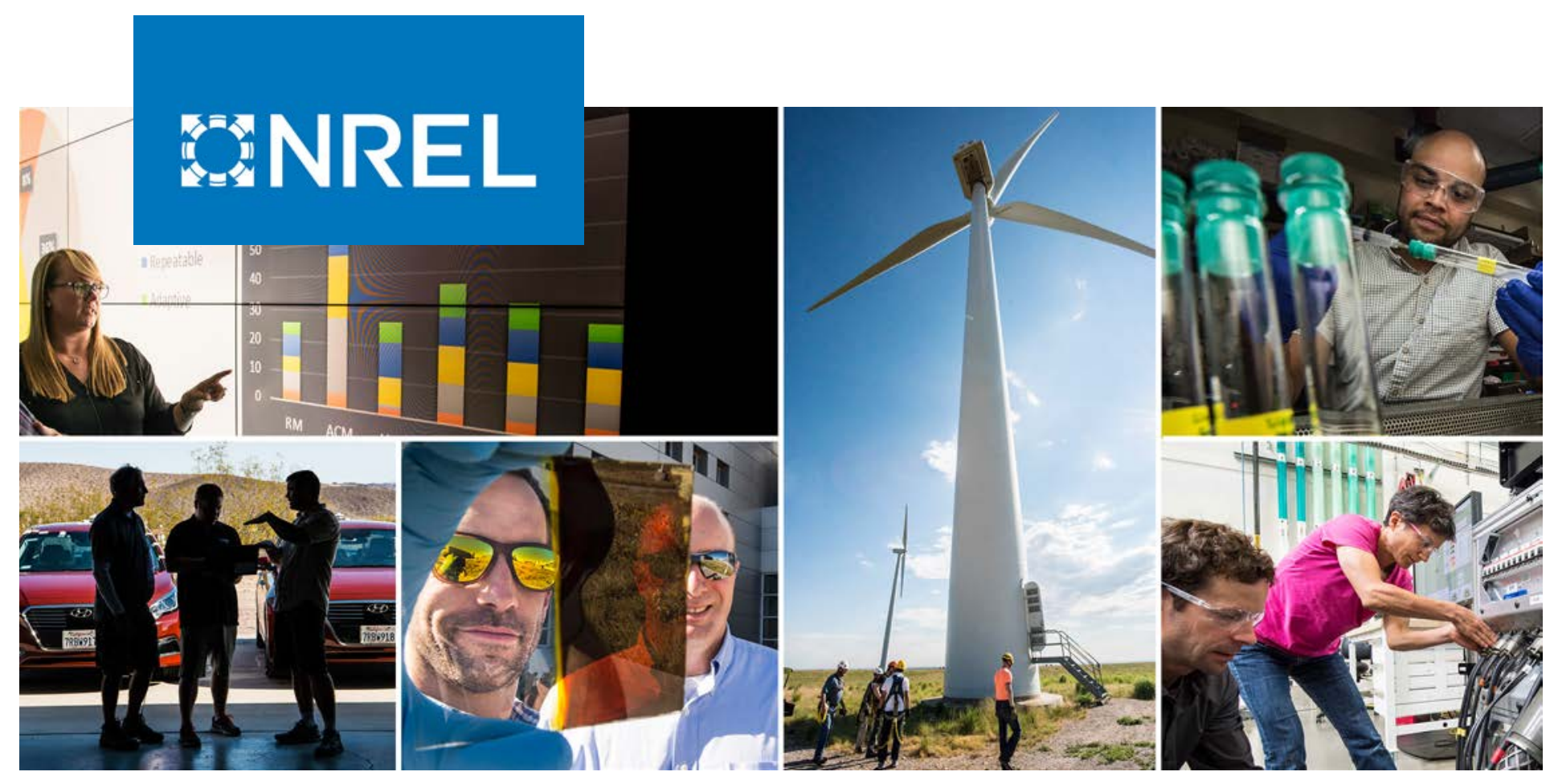

Potential Roles for Demand Response in High-Growth Electric Systems with Increasing Shares of Renewable Generation

Elaine Hale, Lori Bird, Rajaraman Padmanabhan, and Christina Volpi

National Renewable Energy Laboratory

NREL is a national laboratory of the U.S. Department of Energy

Office of Energy Efficiency \& Renewable Energy

Operated by the Alliance for Sustainable Energy, LLC

This report is available at no cost from the National Renewable Energy Laboratory (NREL) at www.nrel.gov/publications.
Technical Report

NREL/TP-6A20-70630

December 2018 


\title{
GHREL
}

\section{Potential Roles for Demand Response in High-Growth Electric Systems with Increasing Shares of Renewable Generation}

\author{
Elaine Hale, Lori Bird, Rajaraman Padmanabhan, \\ and Christina Volpi
}

National Renewable Energy Laboratory

\author{
Suggested Citation \\ Hale, Elaine, Lori Bird, Rajaraman Padmanabhan, and Christina Volpi. 2018. Potential \\ Roles for Demand Response in High-Growth Electric Systems with Increasing Shares of \\ Renewable Generation. Golden, CO: National Renewable Energy Laboratory. \\ NREL/TP-6A20-70630. https://www.nrel.gov/docs/fy19osti/70630.pdf.
}

NREL is a national laboratory of the U.S. Department of Energy Office of Energy Efficiency \& Renewable Energy Operated by the Alliance for Sustainable Energy, LLC

This report is available at no cost from the National Renewable Energy Laboratory (NREL) at www.nrel.gov/publications.

Contract No. DE-AC36-08GO28308
Technical Report NREL/TP-6A20-70630

December 2018

National Renewable Energy Laboratory 15013 Denver West Parkway Golden, CO 80401

303-275-3000 • www.nrel.gov 


\section{NOTICE}

This work was authored by the National Renewable Energy Laboratory, operated by Alliance for Sustainable Energy, LLC, for the U.S. Department of Energy (DOE) under Contract No. DE-AC36-08G028308. Funding provided by U.S. Department of Energy Office of International Affairs. The views expressed herein do not necessarily represent the views of the DOE or the U.S. Government.

This report is available at no cost from the National Renewable Energy Laboratory (NREL) at www.nrel.gov/publications.

U.S. Department of Energy (DOE) reports produced after 1991 and a growing number of pre-1991 documents are available free via www.OSTI.gov.

Cover Photos by Dennis Schroeder: (clockwise, left to right) NREL 51934, NREL 45897, NREL 42160, NREL 45891, NREL 48097, NREL 46526.

NREL prints on paper that contains recycled content. 


\section{Acknowledgements}

The authors are grateful for early reviews from Jaquelin Cochran and Paul Denholm, National Renewable Energy Laboratory (NREL); country-specific reviews from Lehlogonolo Chiloane and Peter Mukoma, Council for Scientific and Industrial Research (CSIR), and from Ella Zhou and David Palchak (NREL); and the insightful comments and suggestions received from Peter Cappers, Lawrence Berkeley National Laboratory (LBNL), Ookie Ma, U.S. Department of Energy (DOE), Brady Stoll and Daniel Steinberg (NREL). We thank Jennifer Daw (NREL) for project management support, and Michael Meshek (NREL) for editing this report. Funding was provided by the DOE's Office of International Affairs under Field Work Proposal No. IA-GTG India SMART Cities DR-FY16-01, "GTG India Demand Response Analysis.” We would particularly like to thank Daniel Noll and Kevin Quinlan (DOE) for their roles in supporting this work. Any errors or omissions are the sole responsibility of the authors. This research was funded under contract number DE-AC36-08GO28308. 


\section{List of Abbreviations and Acronyms}

C\&I
CPP
CPR
CSIR
DER
DLC
DOE
DSM
DRAM
EPRI
ERCOT
EV
FERC
FP\&L
HVAC
ISO
LBNL
MISO
MWh
NE
NREL
NYISO
PURPA
PV
REIPPPP
REV
RTP
ToU
TSO
VPP

commercial and industrial

critical peak pricing

critical peak rebate

Council for Scientific and Industrial Research

distributed energy resource

direct load control

Department of Energy

demand-side management

Demand Response Auction Mechanism

Electric Power Research Institute

Electric Reliability Council of Texas

electric vehicle

Federal Energy Regulation Commission

Florida Power \& Light

heating, ventilation, and air conditioning

independent system operator

Lawrence Berkeley National Laboratory

Midcontinent Independent System Operator, Inc.

megawatt-hour

New England

National Renewable Energy Laboratory

New York Independent System Operator

Public Utilities Regulatory Policy Act

photovoltaic

Renewable Energy Independent Power Producer

Procurement Programme

Reforming the Energy Vision

real-time pricing

time-of-use

transmission system operator

variable peak pricing 


\begin{abstract}
Many countries around the world are experiencing rapid economic development while simultaneously deploying more wind and solar generators. This report explores potential roles for demand response - the modification of electricity load operations to provide grid servicesto support these countries' development goals through enhancing grid reliability and assisting with renewable energy integration in the power sector. After reviewing current demand response programs types, which include wholesale and retail market offerings, as well as broader distributed energy resource (DER) aggregation programs, we reflect on the historical trajectory of demand response as a grid resource and on recent findings from renewable integration studies. The reviewed literature suggests that some types of demand response programs are likely to be more supportive of high-economic growth, high-renewable contexts than others. We conclude by outlining best practices for the design of new demand response programs that build on the historical lessons learned and are well suited to accommodate expected future changes in generation and load patterns.
\end{abstract}




\section{Table of Contents}

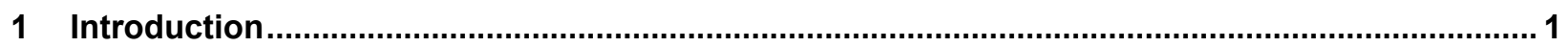



2.1 Demand Response in Wholesale Electricity Markets ......................................................... 3

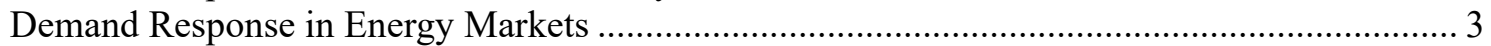

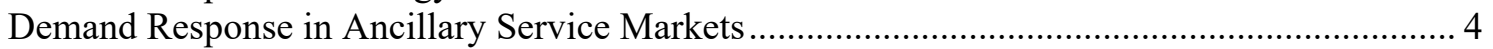

Demand Response in Capacity Markets........................................................................ 5

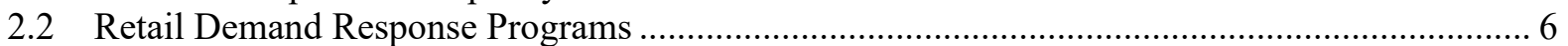

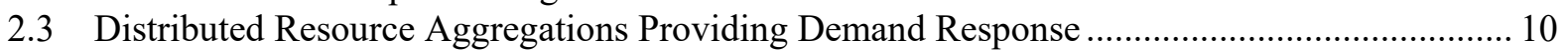

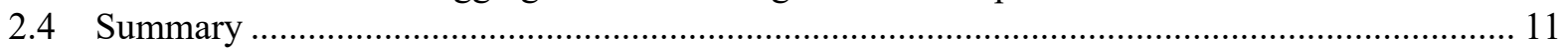

3 Demand Response in High-Growth Power Systems with Increasing Shares of Renewable



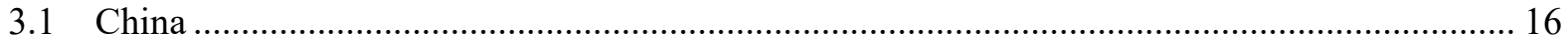

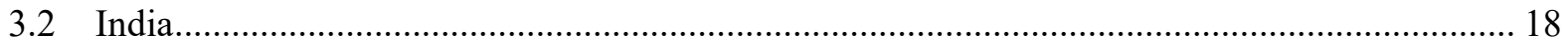

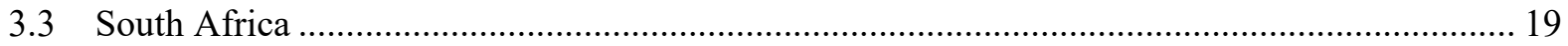

4 Future of Demand Response in High-Growth, Power Systems with Increasing Shares of

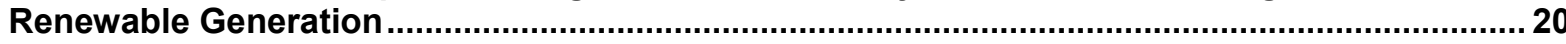

4.1 Comparison of High-Growth Power Systems with Increasing Shares of Renewable Generation with Conditions in the United States When Demand Response Programs Were Originally

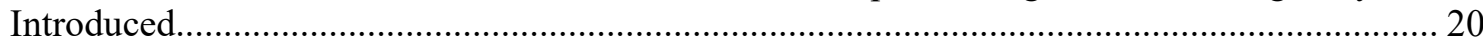

4.2 The Potential for Demand Response to Facilitate Renewable Integration and Emissions

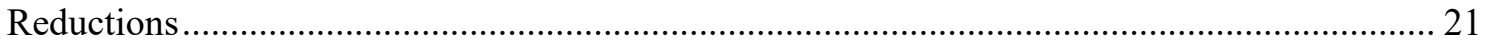

4.3 Framework for Selecting Demand Response Programs ....................................................... 23

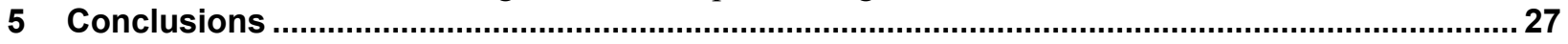

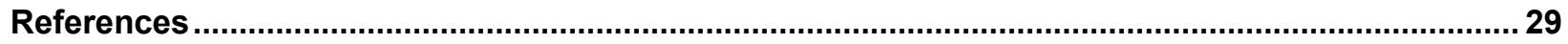




\section{List of Figures}

Figure 1. Global demand response market forecast (Feldman and Lockhart 2014) ................................. 2

Figure 2. Comparison of different dynamic pricing schemes .......................................................... 10

Figure 3. $\mathrm{CO}_{2}$ emissions associated with adding a 300-MW energy-only storage plant to power system models with a total conventional capacity of $15.8 \mathrm{GW}$ and a varying amount of wind and

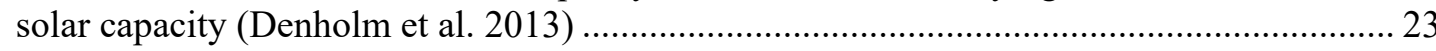

Figure 4. Template of the demand response planning process ........................................................... 26

\section{List of Tables}

Table 1. Comparison of Demand Response Participation in Different Capacity Markets.......................... 5

Table 2. Description of Retail Demand Response Programs Based on Time-Varying Tariffs.................... 6

Table 3. Case Studies of Retail Dynamic Pricing Programs .................................................................... 8

Table 4. Case Studies of Retail Load Control Programs ............................................................... 9



Table 4. Overview of Demand Response Pilot Projects in China....................................................... 17

Table 5. Demand Response Pilot Programs in India........................................................................... 19

Table 6. Demand Response Objectives and Corresponding Demand Response (DR) Options.................. 24 


\section{Introduction}

Demand response, the adjustment of electrical load operations to provide grid services, has been used for decades to make utility operations and planning more efficient and less capital intensive. However, the role of demand response has changed with experience, technological improvements, and power market restructuring. For example, in recent years demand response resources have begun to actively bid energy, capacity, and ancillary services into wholesale power markets in the United States (Murtaugh et al. 2017; ERCOT 2017; ISO-NE IMM 2017; Potomac Economics 2017; Patton, LeeVanSchaick, and Chen 2017; McAnany 2017; Lee et al. 2016). In retail markets, dynamic pricing programs have been piloted and in some cases made permanent (EPRI 2012). Both of these methods for eliciting demand response are aided by recent and still emerging advances in communications and control technology (gtmresearch 2017).

Historically, demand response programs have been initiated during high energy growth periods to help manage system peaks (Hurley, Peterson, and Whited 2013). This and technological changes that have enabled a variety of automatic, dependable demand response control types and their integration into power system operations imply that demand response resources could be a low-cost, flexible, and efficient source of electricity services in emerging economies. Furthermore, relative to new generation and transmission resources, demand response can be deployed quickly. For example, after accepting responses to its request for proposals in January 2004, Independent System Operator (ISO) New England (NE) was able to award a demand response contract for Southwestern Connecticut that was operational by June 2004 (Electric Light \& Power 2008; ISO-NE 2004). The flexibility of demand response can act as a complement to wind and solar photovoltaic (PV) generation (Cappers et al. 2011), which is rapidly being adopted around the world in response to carbon reduction goals and falling costs (REN21 2017).

In this report, we explore the potential for demand response to mitigate costs associated with rapid growth in load, and with renewable energy integration. First, we discuss the variety of roles demand response has fulfilled in wholesale and retail markets both within the United States and internationally. Second, we describe a set of pilot and fully-implemented demand response programs and in China, India, and South Africa - markets that are all experiencing rapid load growth and expanded use of renewable energy generation. The report concludes with a discussion of key considerations for the design and implementation of new demand response programs in wholesale and retail markets. 


\section{Roles for Demand Response}

Historically, demand response was largely used to provide peak load management in the USspecifically, load reduction during contingency events. However, with electricity market restructuring, regulatory reform, and the accelerating adoption of advanced metering and other enabling technologies, demand response in several United States jurisdictions has recently evolved to provide additional system services; in some regions demand response provides a full suite of energy, capacity, and ancillary services. These new services are helping to address operational challenges associated with aging transmission and distribution infrastructure, retirement of older thermal generating units, and increasing penetrations of variable generation. In the future, such services could be provided in other jurisdictions or expanded to provide additional flexibility to aid in the integration of additional variable resources and new technologies such as electric vehicles (Feldman and Lockhart 2014).

The rest of the world has not relied as much on demand response resources as has the United States, even for peak-load management. Given the cost-effectiveness of this traditional role, as well as the maturation of a wider variety of demand response control and service types that can respond to the system needs outlined above, there are new market opportunities for demand response. Feldman and Lockhart (2014) estimate that the global market for demand responseenabling technologies could grow to $\$ 9.7$ billion by 2023 (Figure 1). The Asia-Pacific region in particular is expected to see rapid growth as its electricity markets allow load participation in the provision of energy and ancillary services.

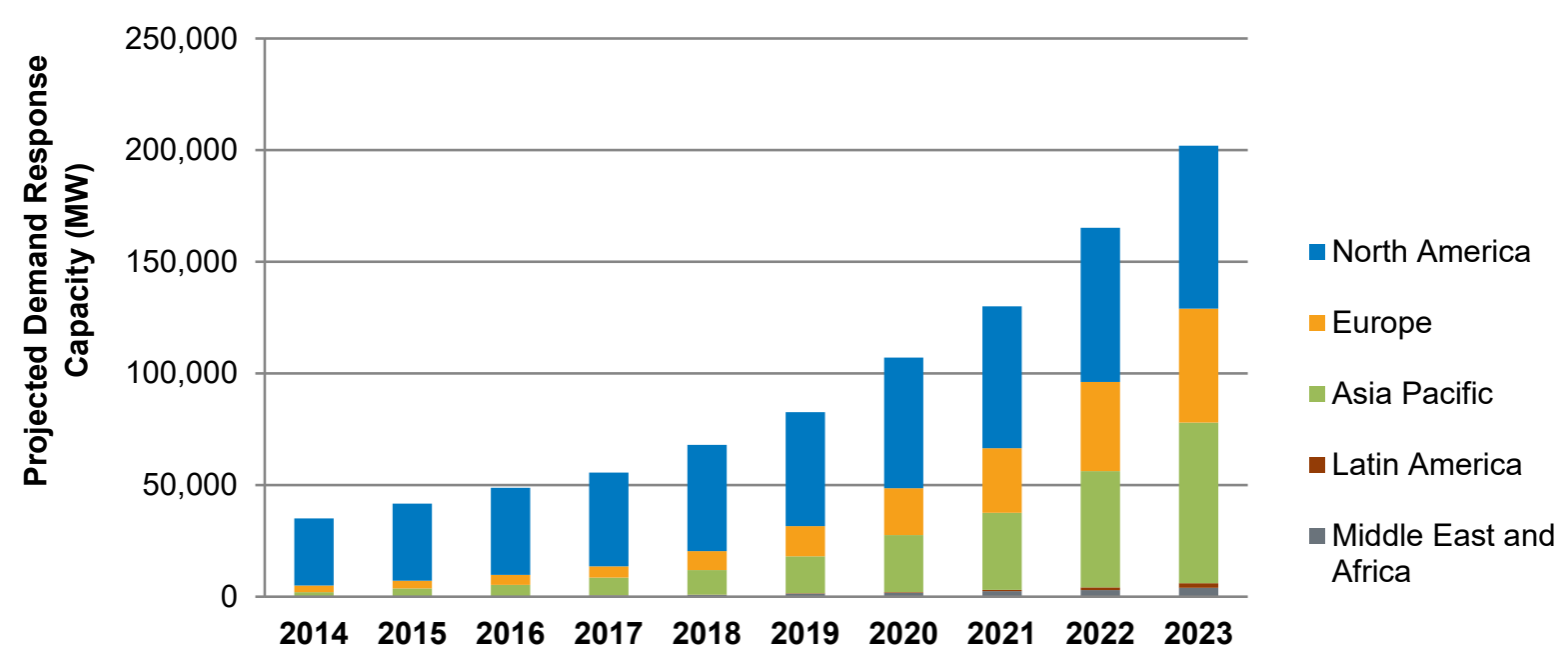

Figure 1. Global demand response market forecast (Feldman and Lockhart 2014)

Depending on context, demand response programs may be implemented in wholesale or retail markets. There are also leading jurisdictions conscientiously working to construct nextgeneration power systems with an emphasis on variable generation, load flexibility, and other supporting technologies. Utilities and system operators seeking to integrate demand-side resources for the first time or in new ways can benefit from learning about the wide variety of approaches and experiences that have come before. 


\subsection{Demand Response in Wholesale Electricity Markets}

Demand response has been implemented in wholesale electricity markets through regulations and market rules that allow demand response resources to participate side-by-side with supplyside resources in energy, ancillary service, and capacity markets. In these markets, demand response has been implemented primarily by allowing load aggregators, that is, traditional loadserving entities or third-party companies focused on providing demand response solutions, to submit load modification or other grid service offers directly into the wholesale market on behalf of their customers. Large customers can also offer load resources directly into markets in some regions, but this practice is less common.

\section{Demand Response in Energy Markets}

There are two potential routes for commercial and industrial (C\&I) facilities to reconcile their marginal value of electricity consumption with market conditions. Very large commercial and industrial (C\&I) facilities may be able to directly bid their load into the wholesale electricity markets; some utilities and competitive retail providers offer real-time pricing (RTP) via contracts that directly pass through the wholesale electricity price to C\&I customers. The latter option, when available, is often the only option for smaller C\&I customers, because of either explicit market rules on participant size or implicit barriers related to market participant costs. Australia's National Electricity Market is an example of a market in which no direct bidding of large C\&I load is allowed, but utilities do offer RTP contracts (AEMC 2009; Crossley 2011).

Currently, the rules for demand bidding in energy markets vary markedly from market to market. In some energy markets, demand resource bidding is restricted to the day-ahead market (NYISO 2017). In others, demand resources are allowed to participate in both day-ahead and intraday markets (PJM 2017). ISO New England is going through a transitional phase where demand response resources are allowed to place load reduction bids in response to day-ahead locational marginal prices and are then settled at those prices for their bids and real-time prices for any deviations (ISO-NE IMM 2017). In this case, demand response has no effect on the day-ahead prices but does impact the real-time load forecast.

The recent experiences of the California ISO and PJM Interconnection demonstrate how demand bidding in energy markets is still being worked out in practice as a complement to other demand response services rather than as a primary driver. In 2016, the California ISO appeared to experience a shift from most demand response bidding being in the day-ahead market to most being in the real-time market offered at or near the market cap of $\$ 1,000$ per megawatt-hour (MWh) (Murtaugh et al. 2017). In PJM Interconnection, demand response participating in the PJM energy markets (so-called "economic" demand response) comprised less than $5 \%$ of all demand response revenues for each of the fiscal years 2014-2016. ${ }^{1}$ Thus demand response based solely on the economics of buying energy (as opposed to energy bundled with some form of capacity payment) tends to be smaller than what demand response provides in terms of ancillary services and capacity (McAnany 2016, 2017).

\footnotetext{
${ }^{1}$ In 2015, total economic demand response revenues were about $\$ 8$ million out of a total demand response market size of $\$ 800$ million. In 2016, they were about $\$ 3$ million out of total market of around $\$ 650$ million. Economic demand response made up a larger proportion of 2014 revenue, but that still amounted to less than $5 \%$ of the total.
} 


\section{Demand Response in Ancillary Service Markets}

Several wholesale electricity markets in North America, Europe, Singapore, and New Zealand allow demand response resources to participate in the provision of ancillary services. Such markets allow demand response resources to directly compete with supply-side resources to provide contingency reserves and frequency regulation services. Demand response resources provide a substantial portion of reserves in several of these markets; for instance, demand response consistently comprises over $50 \%$ of the responsive (i.e., spinning) reserves in the Electric Reliability Council of Texas (ERCOT) market - the maximum allowed by market rules (Potomac Economics 2016).

Compensation for demand response providing contingency reserves varies from market to market. In some markets, demand response resources receive capacity payments based on their participation in contingency reserve markets. In others, demand response resources are required to participate in contingency reserve/emergency load shedding markets based on their status as a capacity resource that has cleared a capacity market. The Loads as a Resource (LaaR) program in ERCOT (ERCOT 2006) and the U.K. National Grid system operator's Short Term Operating Reserve program (Curtis 2015) are examples of the former; PJM's capacity performance products are examples of the latter.

Although less common than the inclusion of demand response in contingency resources, a number of system operators (e.g., ERCOT, the Alberta Electric System Operator, and systems in the U.K. and Australia) have programs for under-frequency load shedding, which automatically disconnects select loads when a minimum frequency threshold is violated (ERCOT 2017; Ritter 2011; Heffner et al. 2007). This is sometimes a standalone ancillary service, similar to generator governor controls, that operates through fast automatic control rather than market dispatch. In the case of ERCOT, under-frequency load shedding is the mechanism through which many load resources participate in the ancillary service markets (ERCOT 2006, 2017).

In general, demand-side resources are more likely to provide something akin to spinning contingency reserves rather than regulation reserves. In ERCOT in August of 2017, for example, of the 28,970 MW-h of ancillary services provided by demand response, 28,219 MW-h were for responsive reserves (the spinning reserve product mentioned above) and only $751 \mathrm{MW}-\mathrm{h}$ were for regulation reserves. ${ }^{2}$ Similarly, in PJM in 2016 demand response provided 67,801 MW-h of regulation reserve, compared to $827,091 \mathrm{MW}-\mathrm{h}$ of synchronous (contingency) reserve. However, a wide variety of equipment types are registered to provide regulation services in PJM - water heaters, batteries, HVAC, manufacturing, and refrigeration - which demonstrates an increasing level of sophistication in the requisite communication and control technology (McAnany 2017).

\footnotetext{
2 See "Monthly ERCOT Demand Response from Load Resources" (http://mis.ercot.com/misapp/GetReports.do?reportTypeId=13242\&reportTitle=Monthly\%20ERCOT\%20Demand $\%$ 20Response\%20from\%20Load\%20Resources\&showHTMLView=\&mimicKey), which is available from "Load Resource Participation in the ERCOT Markets," ERCOT, http://www.ercot.com/services/programs/load/laar. The Responsive Reserve Service is listed as RRS, regulation appears as RegUp and RegDown.
} 


\section{Demand Response in Capacity Markets}

The main role of demand response in wholesale markets is as a capacity resource (Lee et al. 2016). In formal capacity markets, demand response resources receive capacity payments for being available for curtailment on request. Capacity auctions that allow demand response participation are regularly held by in the United States by PJM, ISO-NE, New York Independent System Operator (NYISO), and the Midcontinent Independent System Operator, Inc. (MISO). ${ }^{3}$ Capacity auctions were held for the second time in the U.K. in 2015 (National Grid 2015). Table 1 summarizes various capacity markets in the United States and the U.K. along with the results for demand response resources in recent auctions (Cappers, Goldman, and Kathan 2010; SEDC 2015; Indo-German Energy Programme 2015).

Table 1. Comparison of Demand Response Participation in Different Capacity Markets

\begin{tabular}{|c|c|c|c|c|}
\hline $\begin{array}{l}\text { System } \\
\text { Operator }\end{array}$ & $\begin{array}{l}\text { Capacity Market } \\
\text { Name and Type }\end{array}$ & $\begin{array}{l}\text { Recent Capacity } \\
\text { Auction Results }\end{array}$ & $\begin{array}{l}\text { Demand } \\
\text { Response } \\
\text { Cleared }\end{array}$ & Remuneration \\
\hline PJM (U.S.) & $\begin{array}{l}\text { Reliability Pricing } \\
\text { Model (RPM); } \\
\text { Capacity obligation }\end{array}$ & $\begin{array}{l}167,305.9 \mathrm{MW} \text { for } \\
\text { the } 2019-2020^{\mathrm{a}} \\
\text { delivery period }\end{array}$ & $10,348 \mathrm{MW}$ & $\begin{array}{l}\text { Capacity payment } \\
\text { based on performance } \\
\text { (fast responsiveness), } \\
\text { with severe penalties }\end{array}$ \\
\hline MISO (U.S.) & $\begin{array}{l}\text { Resource Adequacy } \\
\text { Requirement (RAR); } \\
\text { Capacity obligation }\end{array}$ & $\begin{array}{l}135,483 \mathrm{MW} \text { for } \\
\text { the delivery period } \\
2016-2017^{\mathrm{a}}\end{array}$ & 5,819 MW & $\begin{array}{l}\text { Capacity payment } \\
\text { based on auction } \\
\text { clearing price }\end{array}$ \\
\hline $\begin{array}{l}\text { ISO-NE } \\
\text { (U.S.) }\end{array}$ & $\begin{array}{l}\text { Forward Capacity } \\
\text { Market (FCM); } \\
\text { Capacity auction }\end{array}$ & $\begin{array}{l}35,567 \mathrm{MW} \\
\text { for the } 2019-2020^{* *} \\
\text { delivery period }\end{array}$ & $2,746 \mathrm{MW}$ & $\begin{array}{l}\text { Monthly capacity } \\
\text { payment based on } \\
\text { auction clearing price }\end{array}$ \\
\hline $\begin{array}{l}\text { National } \\
\text { Grid (U.K.) }\end{array}$ & $\begin{array}{l}\text { Electricity Market } \\
\text { Reform (EMR); } \\
\text { Capacity auction }\end{array}$ & $\begin{array}{l}46,350 \mathrm{MW} \text { for the } \\
2019-2020 \text { delivery } \\
\text { period }\end{array}$ & $\begin{array}{r}450 \mathrm{MW} \\
\text { (8 } \mathrm{MW} \text { proven } \\
\text { demand } \\
\text { response) }\end{array}$ & $\begin{array}{l}\text { Monthly capacity } \\
\text { payment based on } \\
\text { auction clearing price }\end{array}$ \\
\hline
\end{tabular}

${ }^{a}$ The delivery period is from June 1-May 31 of the specified years.

Several locations (e.g., Western Australia, France, Ireland, Northern Ireland, Italy, Spain, Greece, and South Korea) have capacity markets in place that do not seem to have explicit demand-side provisions (Spees and Newell 2014; RTE France 2014; Indo-German Energy Programme 2015; SEDC 2015). Capacity market mechanisms are emerging in the Nordic countries, ${ }^{4}$ and transmission system operators (TSOs) in different European countries are looking at different procurement mechanisms for demand-side participation in the long term. Taking the grid-interconnected Nordic countries as an example, Finland and Sweden manage capacity with strategic reserve or peak load reserve strategies, which are similar to contingency reserves and involve holding a certain amount of capacity that is activated only when the energy market, Elspot, demonstrates a capacity shortage. Denmark has recently initiated a similar strategy.

\footnotetext{
${ }^{3}$ In light of recent rules implemented at PJM that require all cleared capacity to be part of a new capacity performance product available year-round, participation of demand response resources could be affected in future auctions. Demand response aggregators can combine different seasonal demand response resources to create a yearround capacity resource; it is unclear how much demand response capacity will be unmatchable in this new scheme.

${ }^{4}$ Excluding Iceland, which has a unique, islanded power system consisting of hydro and geothermal generators.
} 
Norway manages capacity needs through a tertiary balancing market that provides capacity through seasonal and weekly auctions. All these mechanisms allow demand-side participation, but increasing the share of demand response may be difficult because of performance requirements and low electricity prices. For example, Sweden initially had a goal to replace the strategic reserve with an all demand-side market mechanism by 2020 , but has since dropped the goal of phasing out generators from providing that service (THEMA Consulting Group 2015).

\subsection{Retail Demand Response Programs}

Many countries that have not undergone electric market restructuring and do not operate wholesale electricity markets nevertheless have utilities that offer demand response opportunities to residential, commercial, and industrial consumers at the retail level, mostly through timebased tariffs, dynamic pricing programs, interruptible load tariffs, and direct load control programs.

Time-based tariffs and dynamic pricing programs incent customers to shift electricity use from on-peak to off-peak times by exposing them to time-varying price signals. Dynamic pricing programs especially come in a variety of forms. Altogether, the major time-varying price schemes are time-of-use (ToU) tariffs, real-time pricing (RTP), critical peak pricing (CPP), critical peak rebates (CPR), and variable peak pricing (VPP) (Table 2).

Table 2. Description of Retail Demand Response Programs Based on Time-Varying Tariffs

\begin{tabular}{ll}
\hline Pricing Mechanism & Description \\
\hline Time-of-use pricing & $\begin{array}{l}\text { As one of the earliest pricing techniques used for decades, ToU pricing } \\
\text { consists of a stepped rate structure that includes a peak rate, an off-peak rate } \\
\text { (and perhaps a shoulder-peak rate) for predetermined blocks of time. The } \\
\text { definition of peak times and the associated rates often varies seasonally. }\end{array}$ \\
\hline Real-time pricing & $\begin{array}{l}\text { Real-time pricing is a dynamic pricing scheme that reflects the variation of } \\
\text { wholesale electricity prices. Customers enrolled in RTP schemes are exposed } \\
\text { to the actual cost of energy for each hour of the day as determined in a } \\
\text { wholesale day-ahead market, in a utility's day-ahead unit commitment } \\
\text { algorithms, or (less commonly) in a wholesale real-time market. }\end{array}$ \\
\hline Critical peak pricing & $\begin{array}{l}\text { Critical peak pricing is a tariff that adds a time-dependent rate to the normal } \\
\text { rate (or ToU rate) based on day-ahead demand forecasts so that the energy } \\
\text { prices are sufficiently high during actual peak demand hours to induce reduced } \\
\text { consumption. The number of days in which CPP rates are applied is usually } \\
\text { limited, and the activation of these rates can range from one day ahead to a } \\
\text { few minutes prior to the peak load event. }\end{array}$ \\
\hline Critical peak rebate & $\begin{array}{l}\text { With a critical peak rebate program, the peak demand periods or emergency } \\
\text { events are anticipated by the utility are relayed to their customers, and the } \\
\text { provision of load curtailments by customers during those periods are } \\
\text { remunerated pro rata at a predefined rate offered by the utility. }\end{array}$ \\
\hline Variable peak pricing & $\begin{array}{l}\text { Variable peak pricing is a combination of ToU and RTP where the on-peak and } \\
\text { off-peak periods are defined in advance (based on anticipated peak demand } \\
\text { periods), but the on-peak prices vary based wholesale market prices or } \\
\text { system lambdas. }\end{array}$ \\
\hline
\end{tabular}

These mechanisms differ with regards to the amount of and frequency with which information must be exchanged between utilities and customers. For a long time, RTP schemes have been 
held up as the ideal for achieving alignment between customer incentives and system needs so as to reduce overall electricity costs for non-participants as well as participants (Borenstein 2005; FERC et al. 2009). However, implementing an RTP requires constant communication between system operators and customers. In contrast, ToU tariffs are calculated and communicated well ahead of time; and CPP, CPR, and VPP only require communication during peak load times. These mechanisms therefore carry much lower informational burdens that can be satisfied with messages conveyed to customers via mail, e-mail, or text message and interval metering of electricity use.

Table 3 summarizes several recent implementations of time-varying pricing programs by utilities. We choose to highlight examples that engaged fairly large proportions of customers within the affected utility service territories. Italy instituted ToU pricing for all customers after it rolled out smart meters in 2011, but it experienced relatively modest customer load shifting because of a relatively modest difference in peak and off-peak pricing. This was exacerbated by substantial growth in PV during early implementation (nearly 17 gigawatts [GW] of PV were installed by 2013), which further drove down the price difference between on-peak and off-peak prices. The Baltimore Gas \& Electric critical peak rebate program in Maryland resulted in significant shifts in consumer demand (on the order of $30 \%$ reduction in load) during emergency events. A study of the Commonwealth Edison (ComEd) program showed maximum hourly prices were lower in the market after ComEd implemented their real-time pricing pilot. These examples demonstrate that there are a range of options for implementing programs and success can depend on implementation and design details. 
Table 3. Case Studies of Retail Dynamic Pricing Programs

\begin{tabular}{|c|c|c|}
\hline Case Study & Program Background & Consumer Response and Impact \\
\hline ToU Rates: Italy & $\begin{array}{l}\text { After completing the rollout of smart } \\
\text { meters to all customers in } 2011 \text {, Italy } \\
\text { introduced a mandatory ToU tariff for } \\
\text { nearly } 20 \text { million residential customers } \\
\text { with on-peak prices from } 8: 00 \text { a.m. to } \\
\text { 7:00 p.m. on weekdays, and lower off- } \\
\text { peak prices at other times. The } \\
\text { difference between on- and off-peak } \\
\text { prices was modest. The rapid increase in } \\
\text { adoption of PV at this time contributed to } \\
\text { the lack of substantial price difference } \\
\text { (Maggiore et al. 2013) }\end{array}$ & $\begin{array}{l}\text { The energy cost savings achieved by all } \\
\text { residential customers from July } 2010 \text { to } \\
\text { June } 2012 \text { was estimated at } 6.45 \text { million } \\
\text { euros ( } 1 \text { Euro cents(c€) per customer- } \\
\text { month). A monthly average load shifting } \\
\text { of less than } 1 \% \text { was observed from peak } \\
\text { to off-peak hours. No significant } \\
\text { difference between average load shifting } \\
\text { occurred between on-peak and off-peak } \\
\text { hours (Maggiore et al. } 2013) \text {. Another } \\
\text { study of the program, focused on the } \\
\text { Trentino province, found that the } \\
\text { introduction of the two-part ToU tariffs } \\
\text { (tariff bioraria) exacerbated the peak } \\
\text { load and increased energy consumption } \\
\text { by nearly } 14 \% \text { (Torriti } 2012 \text { ). }\end{array}$ \\
\hline $\begin{array}{l}\text { RTP: } \\
\text { Commonwealth } \\
\text { Edison (ComEd), } \\
\text { Illinois }\end{array}$ & $\begin{array}{l}\text { After a three-year pilot program, in } 2007, \\
\text { ComEd offered a voluntary RTP program } \\
\text { to all residential customers. The hourly } \\
\text { pricing program allows customers to } \\
\text { have access to hourly energy prices and } \\
\text { the ability to adjust usage accordingly. } \\
\text { Varying factors such as weather, market } \\
\text { conditions, and usage habits determine } \\
\text { the customer's monthly electricity bill } \\
\text { (Commonwealth Edison Company } \\
2017 \text { ). }\end{array}$ & $\begin{array}{l}\text { More than } 10,000 \text { customers enrolled in } \\
\text { the full program. Customers saved } \$ 9- \\
\$ 12 / \text { month on average (about } 15 \%-20 \% \\
\text { of their monthly bill) by shifting energy } \\
\text { use to low price hours. During the pilot } \\
\text { program (2003-2006), the maximum } \\
\text { hourly price was } 12 \text { cents per kilowatt- } \\
\text { hour (kWh), compared to } 38 \text { cents/kWh } \\
\text { during the Illinois energy crisis } 2000- \\
2002 \text { (Star, Isaacson, and Kotewa } 2014 \text { ). }\end{array}$ \\
\hline $\begin{array}{l}\text { Critical Peak } \\
\text { Rebate Program: } \\
\text { Baltimore Gas \& } \\
\text { Electric (BG\&E), } \\
\text { Maryland }\end{array}$ & $\begin{array}{l}\text { BG\&E's Smart Energy Rewards CPR } \\
\text { program is designed to encourage } \\
\text { residential load shifting during peak } \\
\text { hours on selected Energy Savings days. } \\
\text { The program informs customers of a } \\
\text { peak load event the day before it occurs } \\
\text { and offers a rebate for reducing demand. } \\
\text { BG\&E submits load curtailment offers to } \\
\text { the PJM wholesale market and the } \\
\text { incentives are shared with participants. } \\
\text { The average rebate offered at program } \\
\text { launch in } 2013 \text { was } \$ 1.25 / k W h \text {, or nearly } \\
10 \text { times the average residential } \\
\text { electricity price. Residential customers } \\
\text { with smart meters are defaulted into the } \\
\text { program (Harbaugh 2015). }\end{array}$ & $\begin{array}{l}\text { In its pilot from } 2008 \text { to } 2011 \text {, the CPR } \\
\text { program saw an average load reduction } \\
\text { between } 20 \%-30 \% \text { during emergency } \\
\text { events, and customers earned between } \\
\$ 6-\$ 10 \text { per day during these events } \\
\text { (Faruqui and Sergici } 2011 \text {; EPRI } 2012 ; \\
\text { Harbaugh } 2015 \text { ). In } 2013 \text {, the program } \\
\text { had } 300,000 \text { participants who } \\
\text { contributed to an average load reduction } \\
\text { of } 15 \% \text { during the four emergency } \\
\text { events in that year. BG\&E expanded its } \\
\text { program to all its residential customers, } \\
\text { and as of } 2015, \text { nearly one million } \\
\text { residential customers were enrolled and } \\
\text { many saved } \$ 5-\$ 8 \text { on each Energy } \\
\text { Savings day (Harbaugh } 2015 \text { ). }\end{array}$ \\
\hline
\end{tabular}


Direct load control and interruptible load tariffs are also important ways utilities obtain demand response service through retail markets. Table 4 summarizes two examples of direct load control programs recently implemented by utilities. ${ }^{5}$ First, Florida Power \& Light (FP\&L) offers its residential, commercial, and industrial customers incentives for granting FP\&L direct control over air conditioners, water heaters, space heaters, pool pumps, and miscellaneous C\&I equipment deemed suitable and acceptable during a site visit. ${ }^{6}$ Under this program and others like it, participants get a yearly payment in return for the utility being allowed to exercise control over enrolled equipment during times of peak load, with contractual limitations on event frequency and duration. Second, Table 4 describes a pilot project in which BMW and Pacific Gas \& Electric teamed to encourage groups of electric vehicle (EV) chargers to shift their demand in response to utility needs. Because of the success of the first phase of the EV program, a second phase is currently being planned.

Table 4. Case Studies of Retail Load Control Programs

\begin{tabular}{|c|c|}
\hline Program Background & Consumer Response and Impact \\
\hline \multicolumn{2}{|c|}{ Full-Scale Direct Load Control Program, Florida Power \& Light (FP\&L), Florida } \\
\hline $\begin{array}{l}\text { FP\&L maintains large direct load control programs for all } \\
\text { customers. It provides incentives for residential customers to } \\
\text { allow the utility to temporarily shut off or modify the } \\
\text { operations of electric water heaters, air conditioners, space } \\
\text { heaters, and pool pumps during system emergencies. } \\
\text { Commercial customers can enroll air conditioners in a similar } \\
\text { program. The utility will also install direct load controllers on } \\
\text { equipment types determined during site visits as part of their } \\
\text { C\&I demand reduction program, which is incented on a } \\
\text { dollars-per-kW basis (FPSC 2015). }\end{array}$ & $\begin{array}{l}\text { FP\&L estimates taken altogether, their } \\
\text { energy efficiency and demand } \\
\text { response programs have superseded } \\
\text { about } 6,000 \mathrm{MW} \text { of capacity, of which } \\
\text { about a third is attributable to demand } \\
\text { response (FPL 2016). }\end{array}$ \\
\hline \multicolumn{2}{|c|}{ Electric Vehicle Direct Load Control Program, Pacific Gas and Electric (PG\&E), California } \\
\hline $\begin{array}{l}\text { The ChargeForward pilot program established by BMW and } \\
\text { PG\&E explores EV charging demand response. Phase I of } \\
\text { the pilot ran from July } 2015 \text { to December } 2016 \text {, and Phase II } \\
\text { will run from } 2018 \text { to } 2020 \text {. During Phase I, PG\&E sent } \\
\text { signals to BMW requesting a load reduction of up to } 100 \mathrm{~kW} \text {. } \\
\text { In response, BMW selected participating vehicles to delay } \\
\text { charging. One hundred BMW i3 owners participated and } \\
\text { were paid } \$ 1,000 \text { up front plus an additional payment up to } \\
\$ 540 \text { based on the level of participation. Customers were } \\
\text { notified by BMW of the charging delay, and the customer } \\
\text { could participate or opt-out. BMW is also using a back-up } \\
\text { storage supply to respond to PG\&E demand response } \\
\text { requests (BMW Group and Pacific Gas and Electric } \\
\text { Company 2017). }\end{array}$ & $\begin{array}{l}\text { Phase I of the ChargeForward program } \\
\text { resulted in nearly } 200 \text { demand } \\
\text { response events taking place over the } \\
18 \text {-month period, } 94 \% \text { of which } \\
\text { reached the grid reduction target of } 100 \\
\text { kW. From July } 2015 \text { to August } 2016, \\
\text { more than } 19,000 \text { kWh of load was } \\
\text { shifted from at-home EV charging to } \\
\text { compensate for the grid demand. And, } \\
92 \% \text { of participants indicated they were } \\
\text { satisfied with the program (Pacific Gas } \\
\text { and Electric Company 2016). }\end{array}$ \\
\hline
\end{tabular}

\footnotetext{
${ }^{5}$ A running list of such programs in the United States is maintained at "Residential Demand Response Programs," ClearlyEnergy, https://www.clearlyenergy.com/residential-demand-response-programs, last updated October 10, 2016.

${ }^{6}$ In general, C\&I traditional interruptible load tariffs are evolving to resemble the newer direct load control programs with regards to being implemented via reliable, automated controls.
} 
Overall, these tariff and incentive programs vary in the extent to which they can align customer prices with system costs and in the amount of complexity and risk experienced by individual customers. Figure 2 illustrates these trade-offs. Although RTP appears to have the most potential to align customer and system incentives, at a minimum its implementation requires advanced metering infrastructure and it has the potential to expose customers to a high degree of price risk. At the other extreme, ToU tariffs are much simpler to implement and less risky to customers, but only provide a very blunt (season and time-of-day) and static (determined a year or more ahead of time) price signal that may not be sufficient to alleviate the worst peak load conditions. Interruptible tariffs, direct load control (DLC) programs, and programs aimed directly at peak load conditions (i.e., CPP/CPR and VPP) represent an interesting middle ground.

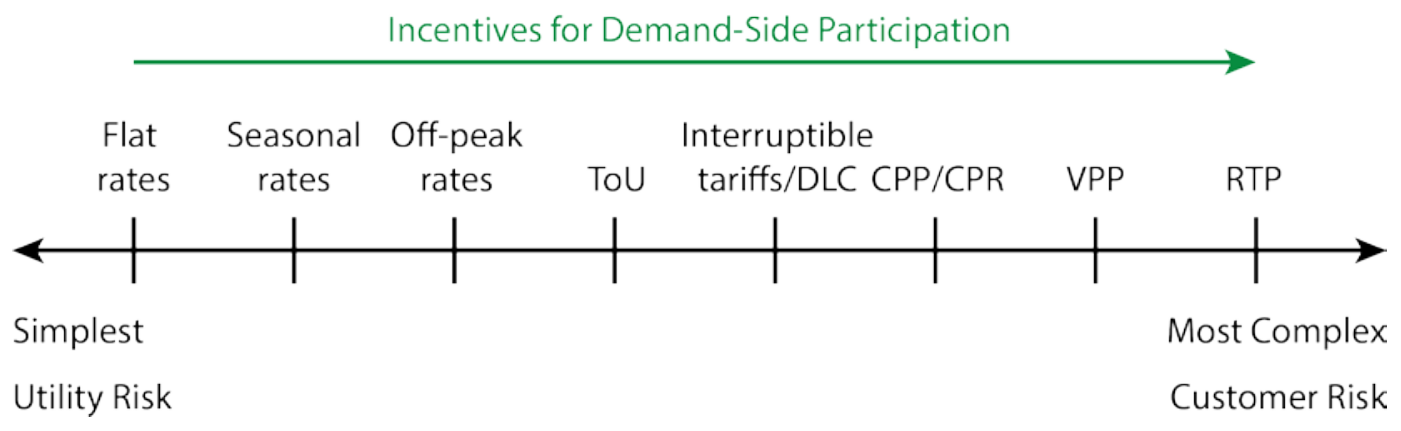

Figure 2. Comparison of different dynamic pricing schemes

\subsection{Distributed Resource Aggregations Providing Demand Response}

In the United States, the states of California and New York have recently developed initiatives to promote demand response programs that include distributed energy resource participation in wholesale markets to better facilitate renewable energy resource integration and to manage power flows in the distribution system (CPUC 2015; NYPSC 2016). These efforts are designed to support distributed energy resource deployment and bring more demand-side aggregations into the wholesale markets for effective side-by-side participation with supply resources. New York has an additional goal of facilitating the engagement of customers in energy transactions. California's efforts are more directly focused on supporting their greenhouse gas reduction goals, which have already had significant impacts on the state's generation mix (Lyons and Kassakhlan 2016).

California's Demand Response Auction Mechanism (DRAM) (CPUC 2015), which began accepting bids in late 2015, is one such initiative where load aggregations greater than $100 \mathrm{~kW}$ are procured by the three large investor-owned utilities in the state (Pacific Gas \& Electric, San Diego Gas \& Electric, and Southern California Edison) to provide increased flexibility for the system. California's DRAM is intended to expand the demand response markets by allowing the aggregation of distributed energy resources that can provide load response (e.g., smart thermostats, EV charging, behind-the-meter batteries, and commercial and industrial responsive loads). Under the program, load aggregators can make offers (of at least $100 \mathrm{~kW}$ ) into the California ISO day-ahead market through the Proxy Demand Resource Program. The revenue for load curtailments in the DRAM mechanism will be entirely shared with participating customers. The initial DRAM pilot auction had a minimum target of $22 \mathrm{MW}$ (10 MW each for Pacific Gas 
\& Electric and Southern California Edison, and $2 \mathrm{MW}$ for San Diego Gas \& Electric), and at least $20 \%$ of the capacity must come from the residential sector. In its opening auction in 2015 , the three investor-owned utilities procured more than $40 \mathrm{MW}$ of total capacity, exceeding their minimum targets. A second auction in 2016 yielded another $82 \mathrm{MW}$ of capacity (St. John 2016). The second round of auction participants will be able to participate in both day-ahead and realtime energy markets in 100-kW increments, as well as bid $500 \mathrm{~kW}$ increments into the real-time Reliability Demand Response Resource program (St. John 2016). Several load aggregator startups and new markets for smart thermostats and other smart devices also emerged as a result of this initiative.

New York has been implementing electric sector reforms under its Reforming the Energy Vision (REV) initiative, which is designed to empower customers and facilitate distributed energy resources and the integration of clean energy resources into the electric system. The state has a renewable portfolio standard goal of 50\% renewable penetration by 2030 .

In line with the REV objectives, the New York Independent System Operator (NYISO) initiated a road-mapping process and a pilot program to allow aggregations of distributed energy resources (DERs) to participate in the wholesale electricity market. The resulting roadmap called for the aggregation rules to be technology agnostic, so that a DER aggregation could consist of different technologies (e.g., storage, distributed generation, and demand reduction) that are collectively able to follow dispatch instructions. The aggregations will be at least $100 \mathrm{~kW}$ in size and must be comprised of resources that are connected at the same transmission node. The aggregations can be coordinated by a customer, a distribution system platform provider, or a third-party. DERs could potentially have dual participation in retail and wholesale markets (Pigeon 2017). The NYISO is in the process of implementing a pilot program that is scheduled for 2018 to demonstrate the dispatchability of the DERs and ensure they can meet performance standards (Yung 2017).

\subsection{Summary}

There are many types of demand response programs distinguished by the markets in which they operate, whether participation is obtained through direct incentives or time-dependent pricing, and their sectoral or end-use specificity. The effectiveness of most demand response programs also depends on the degree to which response is automated. Demand response programs are starting to grapple with their compatibility with increasing amounts of wind and solar generation; California and New York are explicitly working to ensure demand response supports their renewable energy goals, and Italy has had the experience of a ToU structure quickly becoming out of date because of a rapid increase in PV capacity.

In Table 3, we qualitatively summarize the characteristics of different demand response program types with regard to:

- The quality of the response they can provide in terms of certainty, magnitude, and speed

- How robust they are to changing conditions (e.g, increases in wind and solar penetration)

- How difficult they are to establish in terms of infrastructure requirements, time to establish, and cost to establish 
- How acceptable they are likely to be to customers based on intrusiveness and customer price risk

This qualitative assessment was assembled based on the examples described above, as well as other relevant reviews, including EPRI (2012), Cappers et al. (2011), Faruqui, Sergici, and Sharif (2010), Faruqui and Sergici (2010), and Barbose, Goldman, and Neenan (2004). 
Table 3. Characteristics of Demand Response Programs

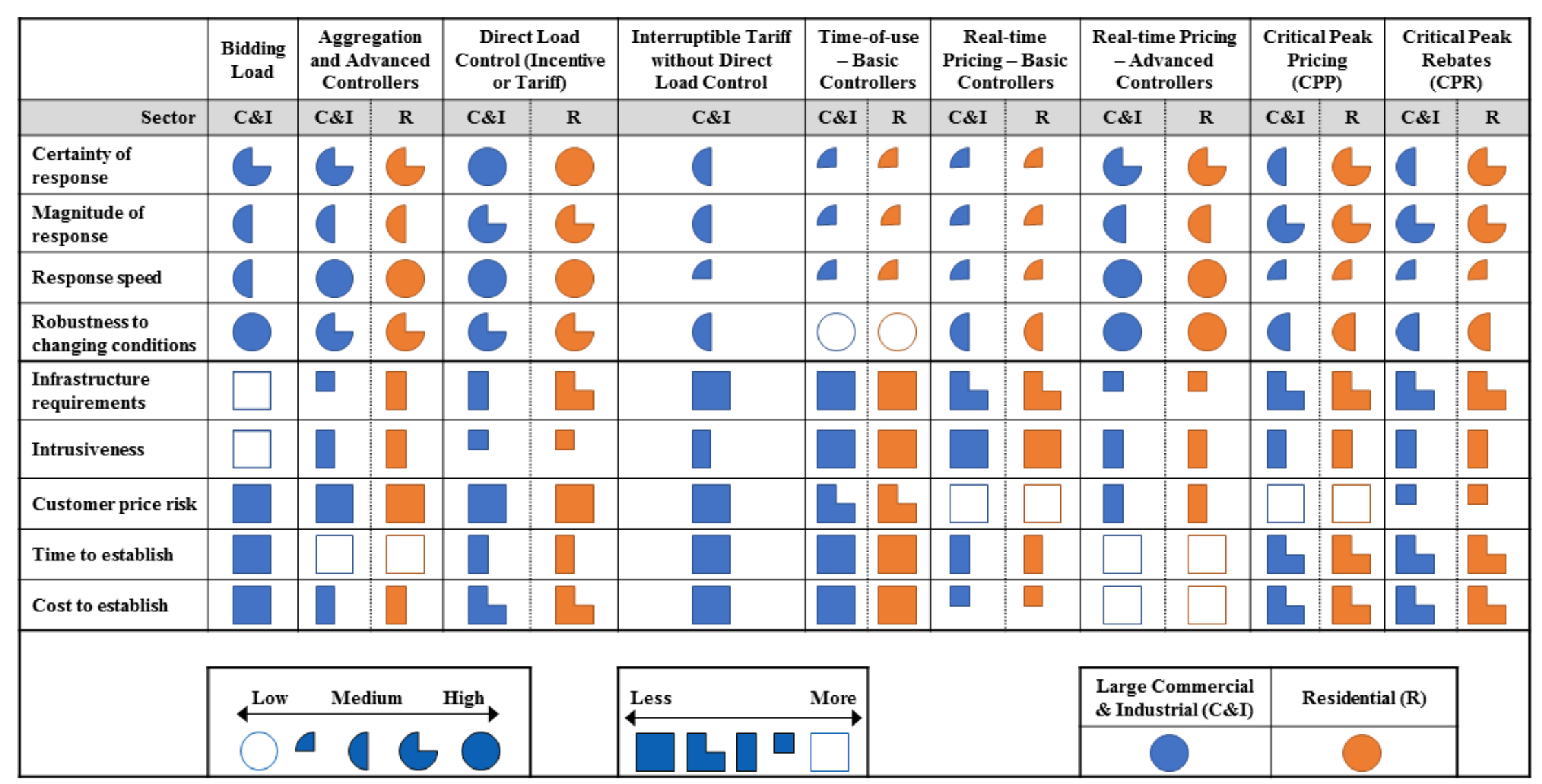

This report is available at no cost from the National Renewable Energy Laboratory at www.nrel.gov/publications. 
While old-style demand response programs (i.e., interruptible tariffs not assisted by direct load control implementation, and ToU tariffs) are generally easy and inexpensive to implement, they do not provide responses that are as large, certain, or fast as those assisted by automatic controls and/or enforced by market settlement processes. Time-of-use tariffs especially, and any contract terms that limit events to typical peak (net) load times, are not robust to changes in solar and wind penetration, as the time of peak net load may shift (in the case of more solar) or become more volatile (in the case of more wind). Time-of-use rates can be designed with solar power specifically in mind, as in California's new matinee energy pricing pilots, which will offer lower prices to commercial, industrial, and agricultural customers midday, correlated with times of high production from PV plants (CPUC 2016); however, the variability of wind in particular may preclude the reliable design of a robust ToU rate for high wind penetration systems.

These deficiencies generally point to following the trend for demand response programs that are more formal and automated. With an aggregation or direct load control contract, both the utility or aggregator and the customer are clear about what service is being purchased and at what price, especially as the program ages and experience accumulates. A much-discussed alternative to that paradigm is the real-time pricing tariff, but there are two potential issues to be considered. First, effective response to a real-time pricing signal requires automated controls. Without them, response requires continually monitoring the price of electricity, which is either (1) not worth the time if the utility bill is a small portion of expenses or (2) a stressful and risky burden if energy costs are a large part of the household or company budget. Second, if automated response to realtime prices becomes widespread enough, it becomes imperative for that response to be accounted for in the price formation process. If this is not done, system balancing can become unstable (Roscoe and Ault 2010; Roozbehani, Dahleh, and Mitter 2010).

On the commercial and industrial side, automated control and metrology is generally required for modern demand response programs. These C\&I demand response programs vary in the services provided, from emergency or contingency response, to economic dispatch, to regulation reserve. The utilities or system operators generally propose, launch, and revise the programs over time, depending on system needs, load characteristics, enrollment numbers, and performance levels. ${ }^{7}$ These programs certainly do not take as long to go from conception to maturity as building new transmission lines does, but the process does typically take several years (Zarnikau 2010). Challenges remain regarding the integration of demand response into markets and utility operations. For example, energy-shifting demand response is likely mis-incentivized in current systems because the make-up energy needed for energy shifting is not factored into day-ahead unit commitment processes.

Automated demand response programs in the residential sector typically take the form of direct load control of appliances such as air conditioners and water heaters. More recently, aggregations of programmable controlled thermostats have been added to the mix, and control of EV charging has been piloted and could be scaled up over the coming decades. All these controllers are operated similarly to modern C\&I programs, with either the utility or an aggregator issuing control signals (on/off, setpoint changes, or price signals that can then be factored into user preferences). In the case of third-party aggregators, they may work directly with a vertically integrated utility or bid their aggregated capacity into a wholesale market. These

7 “Demand Response,” PJM, http://www.pjm.com/markets-and-operations/demand-response.aspx 
programs have the advantage of being able to respond appropriately to actual power system conditions. On the potentially negative side, they do come with significant hardware and communications requirements, and with the potential to feel intrusive to home owners.

Critical peak pricing programs are interesting as a potential compromise between old-style and newer-style demand response programs. If customers have interval meters, no additional infrastructure is needed to implement a critical peak pricing program, as the utility can declare a critical peak pricing event a day ahead of time through basic e-mail or text messages. Then, if such events are infrequent enough and the incentives large enough, customers may be willing to manually adjust the amount of electricity they use during the declared times. However, a caution similar to that regarding including the response to real-time prices in price formation appliesif enough people participate in a critical peak pricing program, the result may be to simply shift the peak to right before or right after the event window. 


\section{Demand Response in High-Growth Power Systems with Increasing Shares of Renewable Generation: Current Trajectories and Aspirations}

Demand response could play a larger role in countries and regions that are experiencing rapid load growth. In fact, new demand response programs are emerging in Asia, Africa, and other regions for reasons such as growing energy demand, grid congestion, aging infrastructure, and an interest in deferring generation and transmission investments. Goals to increase the use of clean energy resources could drive further interest in the use of demand response in these regions going forward. The following case studies explore efforts to implement demand response and the factors driving emerging programs in China, India, and South Africa.

\subsection{China}

As a large industrial nation with a forecasted peak load of about one terawatt by 2020 (Lin, Liu, and Karl 2016), China is a potentially large market for demand response. Also, the country has experienced chronic shortages in power availability because of rapid economic growth, a situation that has ebbed in recent years. To manage this mismatch in electricity demand and supply, large industrial customers were instructed to undertake administratively rationed, uncompensated load reductions to reduce peak demand. For example, in 1998, the State Grid Corporation of China established the Demand Response Management Center in the Jiangsu Province, which promoted demand-side management through both energy efficiency and demand response activities. Demand response measures included ToU rate structures, interruptible load programs, and the deployment of energy storage devices (particularly thermal storage for power plants) (Dong, Xue, and Li 2016).

In April 2002, Jiangsu became the first Chinese province to issue its own demand-side management regulations and activate a pilot demand response project that consisted of ToU rate structures, interruptible tariffs, voluntary load shifting, and deployment of storage devices to facilitate load curtailment. With the aim of deferring investments for transmission expansion and the construction of new power plants, the Natural Resources Defense Council conducted demand-side management pilot programs from 2013 to 2015 in four cities in China: Beijing, Tangshan, Foshan, and Suzhou. The main features of these pilot programs are summarized in Table 4 (Stern 2015). Also, Honeywell partnered with the Tianjin Economic-Technological Development Area in 2012 to implement China's first automated demand response (ADR) project (Navigant 2013; Samad, Koch, and Stluka 2016). 
Table 4. Overview of Demand Response Pilot Projects in China

\begin{tabular}{|c|c|c|c|c|}
\hline & Suzhou, Jiangsu & Beijing & $\begin{array}{l}\text { Foshan, } \\
\text { Guangdong }\end{array}$ & Tangshan, Hebei \\
\hline $\begin{array}{l}\text { Programs } \\
\text { Offered }\end{array}$ & $\begin{array}{l}\text { Interruptible load } \\
\text { programs (real- } \\
\text { time and contract } \\
\text { demand } \\
\text { response) }\end{array}$ & $\begin{array}{l}\text { Interruptible load } \\
\text { and peak load } \\
\text { pricing }^{\mathrm{b}}\end{array}$ & $\begin{array}{l}\text { Cooling storage } \\
\text { pricing }^{c}\end{array}$ & $\begin{array}{l}\text { Interruptible load } \\
\text { programs }^{\mathrm{d}}\end{array}$ \\
\hline $\begin{array}{l}\text { Load } \\
\text { Curtailment } \\
\text { Target } \\
(2013-2015)\end{array}$ & $1,000 \mathrm{MW}$ & $800 \mathrm{MW}$ & $450 \mathrm{MW}$ & $400 \mathrm{MW}$ \\
\hline $\begin{array}{l}\text { Targeted } \\
\text { Consumers }\end{array}$ & $\begin{array}{l}\text { Industries and } \\
\text { municipal facilities }\end{array}$ & $\begin{array}{l}\text { Industrial, } \\
\text { commercial, and } \\
\text { municipal facilities }\end{array}$ & $\begin{array}{l}\text { Industries and } \\
\text { municipal facilities }\end{array}$ & Industries \\
\hline $\begin{array}{l}\text { Types of } \\
\text { Projects }\end{array}$ & $\begin{array}{l}\text { Nearly } 400 \\
\text { facilities connected } \\
\text { to a DSM-service } \\
\text { platform for peak } \\
\text { load management }\end{array}$ & $\begin{array}{l}131 \text { projects which } \\
\text { targeted } 45 \\
\text { enterprises for } \\
\text { dynamic pricing }\end{array}$ & $\begin{array}{l}80 \text { energy } \\
\text { efficiency projects } \\
\text { for industries and } \\
30 \text { projects for } \\
\text { peak demand } \\
\text { shaving }\end{array}$ & $\begin{array}{l}35 \text { energy } \\
\text { efficiency projects } \\
\text { for power plants }\end{array}$ \\
\hline $\begin{array}{l}\text { Actual } \\
\text { Response in } \\
2015^{e}\end{array}$ & $\begin{array}{l}2716 \text { customers, } \\
\text { total } 2037 \mathrm{MW} \\
\text { across Jiangsu } \\
\text { Province }\end{array}$ & $\begin{array}{l}74 \text { customers, } \\
71 \mathrm{MW}\end{array}$ & $\begin{array}{l}129 \text { customers, } \\
176 \mathrm{MW}\end{array}$ & NA \\
\hline
\end{tabular}

a Suzhou City Electric Demand Side Management City Pilot Leading Group Office (2015)

${ }^{b}$ Beijing Finance Bureau, Beijing Development and Reform Commission (2013)

c Foshan Economic Information Committee (2015)

d Tangshan Finance Bureau (2013)

e Songsong (2017)

Because the current challenges in China's power system concern over-supply and environmental issues rather than the previous challenges of under-supply, there have been shifts in policy since 2015, starting with State Council Document No. 9 (Pollitt, Yang, and Chen 2017; Dupuy 2016). These shifts include an increased focus on integrated planning and market-based dispatch mechanisms. In accordance with this trend, the government is also encouraging demand-side management pilot regions to employ voluntary price-based mechanisms in place of the conventional quantity-rationing approach (IEA 2017; Liu et al. 2015; Zhao et al. 2015). 


\subsection{India}

Several factors have created potential demand response opportunities in India, including its rapid growth in energy consumption, non-remunerated supply disruptions, and its goals to shift toward cleaner energy sources. Demand response could also help Indian utilities better cover their costs if residential and agricultural consumers shift loads to more favorable times. In recent years, India has faced challenges with supply shortages, including a nearly 3.3\% peak load deficit and an energy shortage of $2.1 \%$ in fiscal year 2015 (Central Electricity Authority 2016). In addition to rapid growth, changes in its generation mix may also encourage adoption of demand response. India has a capacity target of $175 \mathrm{GW}$ renewable energy by 2022 that expands to $40 \%$ non-fossil energy production by 2030 .

Currently, time-varying pricing is not widely used in India; time-of-day tariffs are offered to large commercial and industrial customers in some states. Otherwise, electricity is typically supplied at a predetermined tiered tariff structure, with subsidies for agricultural and residential customer classes that often result in financial losses for the distribution utilities (Badiani, Jessoe, and Plant 2012; Komives et al. 2005). Demand response may be able to mitigate these financial pressures by reducing the per-unit cost of electricity, especially if the demand response is incented from the subsidized sectors. Remuneration for loss of service is also more consistent with the idea of universal electricity access, which is now an explicit goal of the Indian government (Singh 2017).

Since 2012, India has conducted a few commercial and industrial demand response pilot programs. Table 5 presents the features of two pilot studies conducted in Mumbai and New Delhi. The project in New Delhi was India's first OpenADR demonstration. That pilot study involved 144 customers with a total coincident peak load of about $25 \mathrm{MW}$ responding to a total of 17 events. By building type, the $75^{\text {th }}$ percentile of responses ranged from $3 \%$ in educational buildings to $62 \%$ in pumping facilities, with an overall $75^{\text {th }}$ percentile of responses at $10 \%$ of total load (Ghatikar et al. 2015). Honeywell estimates that if similar projects were deployed in the commercial and industrial sectors across all of India, the projects could potentially decrease the country's peak electricity demand by around $7.5 \mathrm{GW}$, or $5 \%$ of total peak demand (Poojary et al. 2015). 
Table 5. Demand Response Pilot Programs in India

\begin{tabular}{lll}
\hline Program Features & Mumbai & New Delhi \\
\hline Electric Utility & Tata Power Mumbai & $\begin{array}{l}\text { Tata Power Delhi Distribution } \\
\text { Limited }\end{array}$ \\
\hline Demand response provider & Customized Energy Solutions & Honeywell \\
\hline Type of program & $\begin{array}{l}\text { Interruptible load services, energy } \\
\text { shifting programs (incentivized) }\end{array}$ & $\begin{array}{l}\text { Interruptible load services } \\
\text { Other features }\end{array}$ \\
$\begin{array}{lll}\text { Interruptible load implemented by } \\
\text { reducing air-conditioning load and } \\
\text { using thermal storage to shift } \\
\text { energy consumption in industrial } \\
\text { process-heating applications }\end{array}$ & $\begin{array}{l}\text { OpenADR 2.0b, the latest } \\
\text { software version in the United } \\
\text { advanced metering infrastructure } \\
\text { to communicate with customers } \\
\text { and dispatch curtailment requests. }\end{array}$ \\
\hline $\begin{array}{l}\text { Peak load } \\
\text { reduction potential }\end{array}$ & $\begin{array}{l}\text { 18 MW (2014) } \\
\text { Commercial and industrial } \\
\text { Target customers }\end{array}$ & $\begin{array}{l}\text { Commercial and industrial } \\
\text { consumers }(>300 \text { kW capacity) }\end{array}$ \\
\hline
\end{tabular}

\subsection{South Africa}

In 2008, South Africa started to experience widespread power outages and increases in electricity prices because of deficiencies in long-term infrastructure planning and investment in prior years. In addition to generally needing to manage for population and economic growth, Eskom, which manages nearly $95 \%$ of South Africa's demand, was working with aging assets with deteriorating performance. This resulted in increased outage rates for generators and transmission lines. Distribution performance was also poor (Newbery and Eberhard 2008).

In addition to embarking on a program of refurbishment and new builds, Eskom partnered with demand response provider Comverge in 2011 to pilot test a demand response market in South Africa. In this program, Comverge managed the first open demand response market in South Africa, which led to the procurement of $500 \mathrm{MW}$ of commercial and industrial responsive load. Comverge also procured and managed $300 \mathrm{MW}$ of this resource itself as a curtailment service provider. The demand response pilot program delivered nearly 15,260 MWh of load reduction over its seven months duration, which included 549.5 event hours (Comverge 2014).

Since that time, Eskom has successfully built new capacity and improved plant availability rates. The South African Department of Energy Renewable Energy Independent Power Producer Procurement Programme (REIPPPP) awarded support to 3,915 MW of renewable capacity over three auction windows (Eberhard, Kolker, and Leigland 2014). Also, economic growth has not been as fast as what was anticipated in 2008. As a result, today Eskom has a surplus of capacity and little to no emphasis on demand response (Eskom 2017). 


\section{Future of Demand Response in High-Growth, Power Systems with Increasing Shares of Renewable Generation}

As shown above, demand response can, has, and could play many roles in power systems. In this section, we consider potential roles for demand response in the context of high-growth systems that also have clean energy goals. Such systems are perhaps best exemplified by India and China.

\subsection{Comparison of High-Growth Power Systems with Increasing Shares of Renewable Generation with Conditions in the United States When Demand Response Programs Were Originally Introduced}

In the United States, demand response programs were initially introduced by vertically integrated utilities in the 1970s, during that period's general energy crisis and when several important factors were at work. Perhaps foremost, the oil embargo in 1973 led to a global increase in energy prices, which, coupled with local intermittent difficulties in purchasing reasonably priced new generators, made the historic electricity demand growth rates of $8 \%-9 \%$ unsustainable, both economically and socially (Bhatnagar and Rahman 1986; U.S. EIA 2016; Hurley, Peterson, and Whited 2013). Centralized air conditioning was widely adopted starting in the late 1960s and early 1970s, which increased peak summer load in many regions. These new load characteristics coupled with the introduction of integrated resource planning in the late 1970s clarified the potential benefits of demand-side management with regard to providing peak capacity and enhanced reliability (Cappers, Goldman, and Kathan 2010). New legislation related to these issues, especially the National Energy Act of 1978, which contained as one of its five statutes the Public Utilities Regulatory Policy Act (PURPA), was instrumental in encouraging more demandside control, including energy conservation and energy efficiency measures (Alliance to Save Energy 2013).

Programs initiated during that time and into the 1980s were primarily comprised of interruptible, curtailable, or ToU tariffs for large commercial and industrial loads. However, the overall effectiveness of these programs may have been marginal. In some jurisdictions, interruptible and curtailable loads were called on so rarely (e.g., less than once per year) that the tariffs functioned more as an unofficial economic incentive than as peaking capacity. Similarly, the vast majority of ToU customers (approximately 75\%), at least as of the early 2000 s, did not actually shift load in response to their ToU price structure (Fryer et al. 2002). ${ }^{8}$ More recent ToU studies also show mixed results, with multiple pilot programs and natural experiments yielding no or very small $(<$ $5 \%$ peak load reductions and elasticities of substitution less than 0.05 ) impacts (Jessoe and Rapson 2015; EPRI 2012). The old-style interruptible and curtailable rates have at this time largely been replaced by more-reliable alternatives.

Several aspects of the United States electricity industry in the early 1970 s, especially the high growth rates and rapid adoption of air-conditioning technologies, are relatable to current conditions in India, China, and similar locales. However, the energy landscape is much different.

\footnotetext{
${ }^{8}$ Relatedly, Borenstein (2005) finds that under the assumption of equal elasticities (and not accounting for crosselasticities), time-of-use rates can only be expected to capture $20 \%$ of the benefits of real-time rates.
} 
Rather than high fuel costs, in the global energy markets low prices are currently the norm; and nations are planning to shift to use more renewable energy in their electricity sectors. Also, developing nations do not have to forge a completely new path but can build on the experiences of others with demand response and different types of energy markets; they can cooperatively learn with others how to integrate what may turn out to be the $21^{\text {st }}$ century equivalent of the air conditioner: the electric vehicle.

Thus, some of the same drivers for implementing demand response are present, including difficulties building infrastructure fast enough to keep up with increasing demand, the potential for peakier loads driven by air-conditioning, and a desire to provide more reliable service; but, this is against a different energy backdrop of low fuel costs, more variable renewable generators, and the potential for widespread EV adoption. Both the high fuel costs of the 1970s and the clean energy goals of today incentivize less fossil fuel use, but while the implication of the former is basic energy efficiency and reducing peak loads, the latter implies the need to provide flexibility across multiple timescales in support of increasing deployments of wind and solar PV. The demand response innovations of the last several decades, and the potential for emerging technologies such as electric vehicles to be operated flexibly, represent an opportunity to quickly transition to providing reliable electricity service with significantly less pollution intensity by ensuring demand response is implemented to serve as a flexible complement to wind and solar PV generation.

\subsection{The Potential for Demand Response to Facilitate Renewable Integration and Emissions Reductions}

As numerous grid integration studies have shown, operational flexibility is an important ingredient to successfully adding more variable generation to the supply mix (Brinkman et al. 2015; Paul Denholm et al. 2016; Bloom et al. 2016; Hale, Stoll, and Novacheck 2018). The most important timescales for flexibility are system-dependent (Mills and Seel 2015). Flexibility pinch points can be reduced by enlarging geographic areas of cooperation (Brinkman et al. 2015) and by reducing minimum generation levels and allowing wind and solar generators to provide reserves (Denholm et al. 2016).

As a potential source for supplying increased flexibility, demand response is particularly attractive because of the smaller capital investment required to enable it. However, demand response is not a single homogeneous resource but rather the ability of many kinds of electrical loads to adjust their operations to perform various grid services. This complexity is both an advantage and a disadvantage when it comes to assessing the ability of demand response to integrate more renewables into power systems. It is an advantage because by harnessing multiple types of electrical load, flexibility needs at multiple timescales may be addressed (Barooah, Buic, and Meyn 2015). It is a disadvantage because developing reliable, time-varying, and geographically specific estimates of the technical and economic potential of various end-uses to provide particular grid services is a large effort requiring significant input data. To date, only rough short- to medium-term estimates have been compiled (Olsen et al. 2013, 1; Gils 2014).

Importing demand response potential estimates, imperfect as they are, into large-scale production cost models used for grid integration studies has provided some initial insights into potential roles for demand response in systems with increasing penetrations of wind and solar PV. 
First, adding demand response as a resource into any cost-minimizing model of power system operations will always reduce costs, but it will not always reduce emissions, especially if emissions are not factored into dispatch decisions. For example, the case study considered in Hummon et al. $(2013,2)$, when combined with average coal and natural gas emissions rates, ${ }^{9}$ shows that demand response increased carbon emissions compared to the system without demand response. This is in line with what has been seen for storage technologies ${ }^{10}$ and has recently been corroborated under a wider variety of conditions simulated for the Florida power system (Hale, Stoll, and Novacheck 2018). For example, Figure 3 shows that for the system studied, adding a 300-MW storage plant increases carbon emissions when wind and solar penetrations are below about $45 \%$ on an annual generation basis but decreases them once penetrations are sufficiently high. The mechanism involved is a switch from storage predominantly enabling coal generation at the expense of natural gas generation at low penetrations to storage reducing the curtailment of enough wind and solar generation to eventually decrease overall emissions at high penetrations (Denholm et al. 2013). Demand response has a similar ability to reduce curtailment in high penetration systems, although its capabilities are generally more constrained (Denholm and Margolis 2016). The exact extent to which demand response can reduce curtailment remains an active area of research.

Another role for demand response in integrating renewables is in the supply of additional reserve products needed to support the variability and uncertainty of wind and solar. Such value stacking is clearly shown in Hummon et al. $(2013,2)$ and Ma et al. (2016). However, it must be cautioned that the amount of reserves needed to integrate wind and solar are not so sizable, such that a large number of new entrants has the potential to quickly saturate ancillary service markets, even at high wind and solar penetrations (Milligan et al. 2010; Hummon et al. 2013; Baker 2016).

\footnotetext{
9 “Frequently Asked Questions: How much carbon dioxide is produced when different fuels are burned?" EIA, https://www.eia.gov/tools/faqs/faq.cfm?id=73\&t=11

${ }^{10}$ Many types of demand response can be interpreted as, or are mathematically equivalent to, electricity storage. For one example, dynamically adjusting heating and cooling set points to change the power draw of a building relies on the building's inherent thermal storage. For another example, scheduling loads such as clothes washing or EV charging achieves a $100 \%$ efficient shift as compared to the less-than-perfect shift achievable by pumped hydro or battery storage.
} 


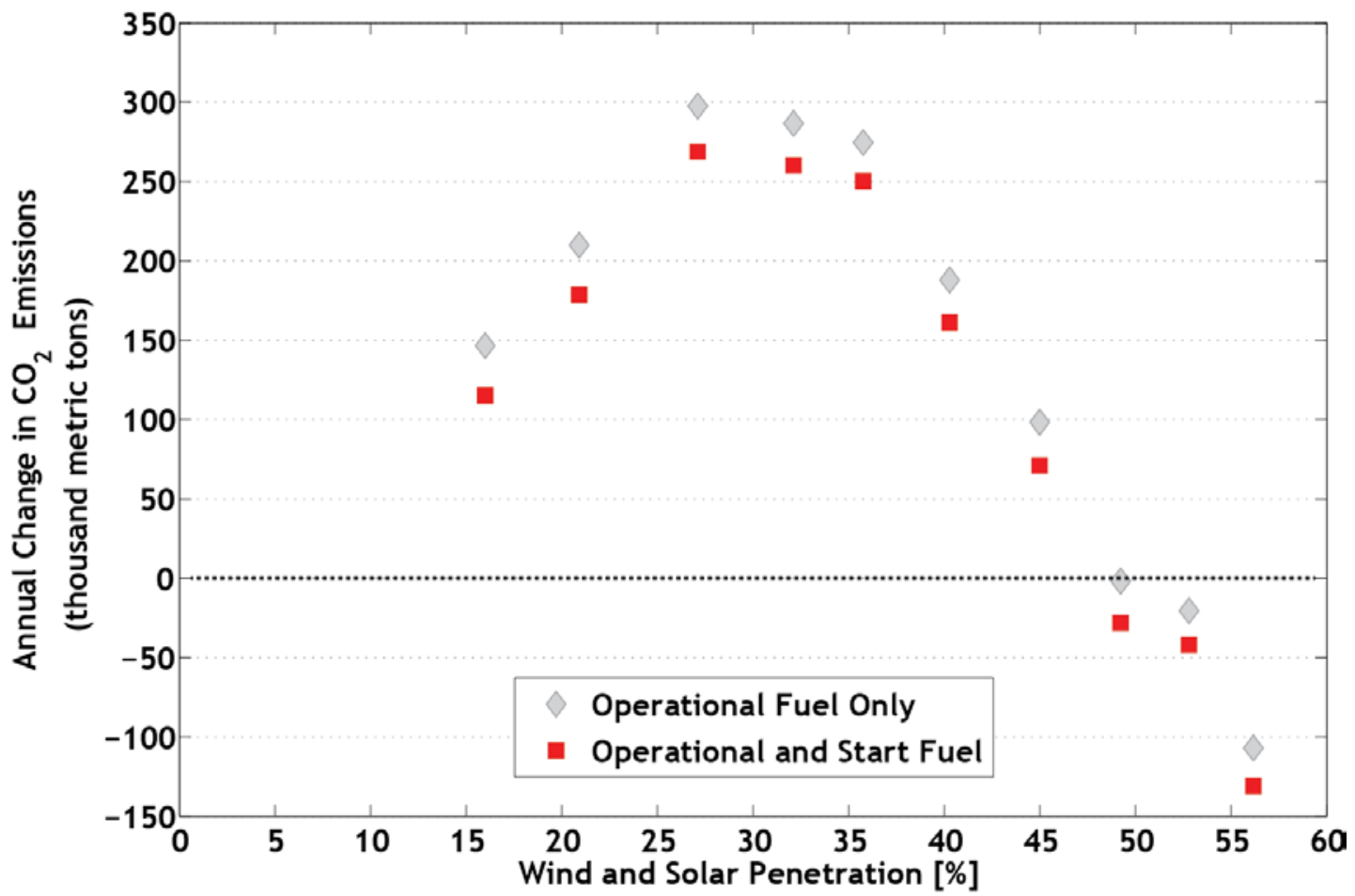

Figure 3. $\mathrm{CO}_{2}$ emissions associated with adding a 300-MW energy-only storage plant to power system models with a total conventional capacity of $15.8 \mathrm{GW}$ and a varying amount of wind and solar capacity (Denholm et al. 2013)

\subsection{Framework for Selecting Demand Response Programs}

From the discussion thus far, it is apparent that demand response is currently used to meet several power system needs and that it may be further called on in the future to help integrate wind and solar. These objectives for demand response are summarized in Table 6 , which further describes the characteristics needed to meet each objective as well as the types of programs that meet those requirements. 
Table 6. Demand Response Objectives and Corresponding Demand Response (DR) Options

\begin{tabular}{|c|c|c|c|}
\hline DR Objectives & DR Role/Benefits & DR Characteristics Needed & DR Options \\
\hline Peak load shifting & $\begin{array}{l}\text { DR can help shift } \\
\text { load at peak } \\
\text { periods. }\end{array}$ & $\begin{array}{l}\text { Customers willing to participate } \\
\text { several to dozens of times per } \\
\text { year } \\
\text { Financial viability } \\
\text { Reliable response }\end{array}$ & $\begin{array}{l}\text { Bidding load } \\
\text { Aggregation } \\
\text { Direct load control } \\
\text { Interruptible tariff } \\
\text { ToU, CPPa, and RTP }\end{array}$ \\
\hline $\begin{array}{l}\text { Regulation } \\
\text { reserves }\end{array}$ & $\begin{array}{l}\text { DR can provide } \\
\text { fast load changes } \\
\text { up or down for } \\
\text { balancing. }\end{array}$ & $\begin{array}{l}\text { Fast response } \\
\text { Binding commitments to provide } \\
\text { response } \\
\text { Automated control to follow } \\
\text { regulation signal }\end{array}$ & $\begin{array}{l}\text { Bidding load } \\
\text { Aggregation and } \\
\text { advanced controllers } \\
\text { Direct load control }\end{array}$ \\
\hline $\begin{array}{l}\text { Contingency } \\
\text { event (emergency } \\
\text { response) }\end{array}$ & $\begin{array}{l}\text { DR can respond to } \\
\text { infrequent } \\
\text { contingency } \\
\text { signals. }\end{array}$ & $\begin{array}{l}\text { Need to ensure certainty, } \\
\text { speed, and continuous } \\
\text { response until the event clears } \\
\text { Binding commitments to provide } \\
\text { response }\end{array}$ & $\begin{array}{l}\text { Bidding load } \\
\text { Aggregation } \\
\text { Direct load control } \\
\text { Interruptible tariff } \\
\text { Frequency sensitive } \\
\text { relays }\end{array}$ \\
\hline $\begin{array}{l}\text { Managing load } \\
\text { growth and } \\
\text { capacity needs }\end{array}$ & $\begin{array}{l}\text { DR can be included } \\
\text { in capacity markets } \\
\text { or long-term } \\
\text { planning. }\end{array}$ & $\begin{array}{l}\text { Relatively rapid program } \\
\text { implementation } \\
\text { Need to ensure certainty, } \\
\text { speed, and continuous } \\
\text { response during peak times } \\
\text { Binding commitments }\end{array}$ & $\begin{array}{l}\text { Bidding load } \\
\text { Aggregation } \\
\text { Direct load control } \\
\text { Interruptible tariff } \\
\text { ToU, CPP, and RTP }\end{array}$ \\
\hline Ramping reserves & $\begin{array}{l}\text { DR can help } \\
\text { address uncertainty } \\
\text { in net-load ramps. }\end{array}$ & $\begin{array}{l}\text { Fast response } \\
\text { Binding commitments to provide } \\
\text { response } \\
\text { Automated control preferred }\end{array}$ & $\begin{array}{l}\text { Bidding load } \\
\text { Aggregation } \\
\text { Direct load control } \\
\text { RTP }\end{array}$ \\
\hline $\begin{array}{l}\text { Virtual energy } \\
\text { storage }\end{array}$ & $\begin{array}{l}\text { DR can help shift } \\
\text { load to periods of } \\
\text { excess generation } \\
\text { (e.g., midday for } \\
\text { high-solar } \\
\text { systems.) }\end{array}$ & $\begin{array}{l}\text { Customers willing or required to } \\
\text { participate } \\
\text { Reliable response }\end{array}$ & $\begin{array}{l}\text { Bidding load } \\
\text { Aggregation } \\
\text { Direct load control } \\
\text { ToU and RTP }\end{array}$ \\
\hline
\end{tabular}

a Whenever CPP is listed, any of CPP, CPR or VPP would be appropriate. 
Utilities and regulators serving high-growth systems with increasing shares of wind and solar generation would do well to keep most if not all these objectives in mind, and to go through a detailed planning process to discern which types of demand response might be most valuable to their systems, when, and where. As shown in Figure 4, for the development of effective demand response programs, understanding local conditions is particularly important. Which grid services are most needed? Which loads are significant in size and are (potentially) controllable? The answers to both these questions may change over time. Capacity and peak load reduction have typically been the most important services provided by demand response, but energy shifting, ramping reserve, and regulation may become more important as wind and solar penetrations increase. For now, in many places, applying direct load control to residential air conditioners might not yet make sense, but that could change in coming years. In some areas, focusing on industrial demand response is a natural choice, while in others, commercial loads are dominant. Once the flexible loads and grid service needs have been identified, potential demand response programs can be listed and screened as to whether they are a good fit for providing the services needed with the loads available. When that list is stabilized, it is time to plan for the time it takes to test and revise those potential programs, and to embark on the processes of pilot program design, recruitment, rollout, and analysis. All along the way, there are many examples to study, colleagues to reach out to, and, increasingly, vendors to consider working with to help ensure the establishment of successful programs. 


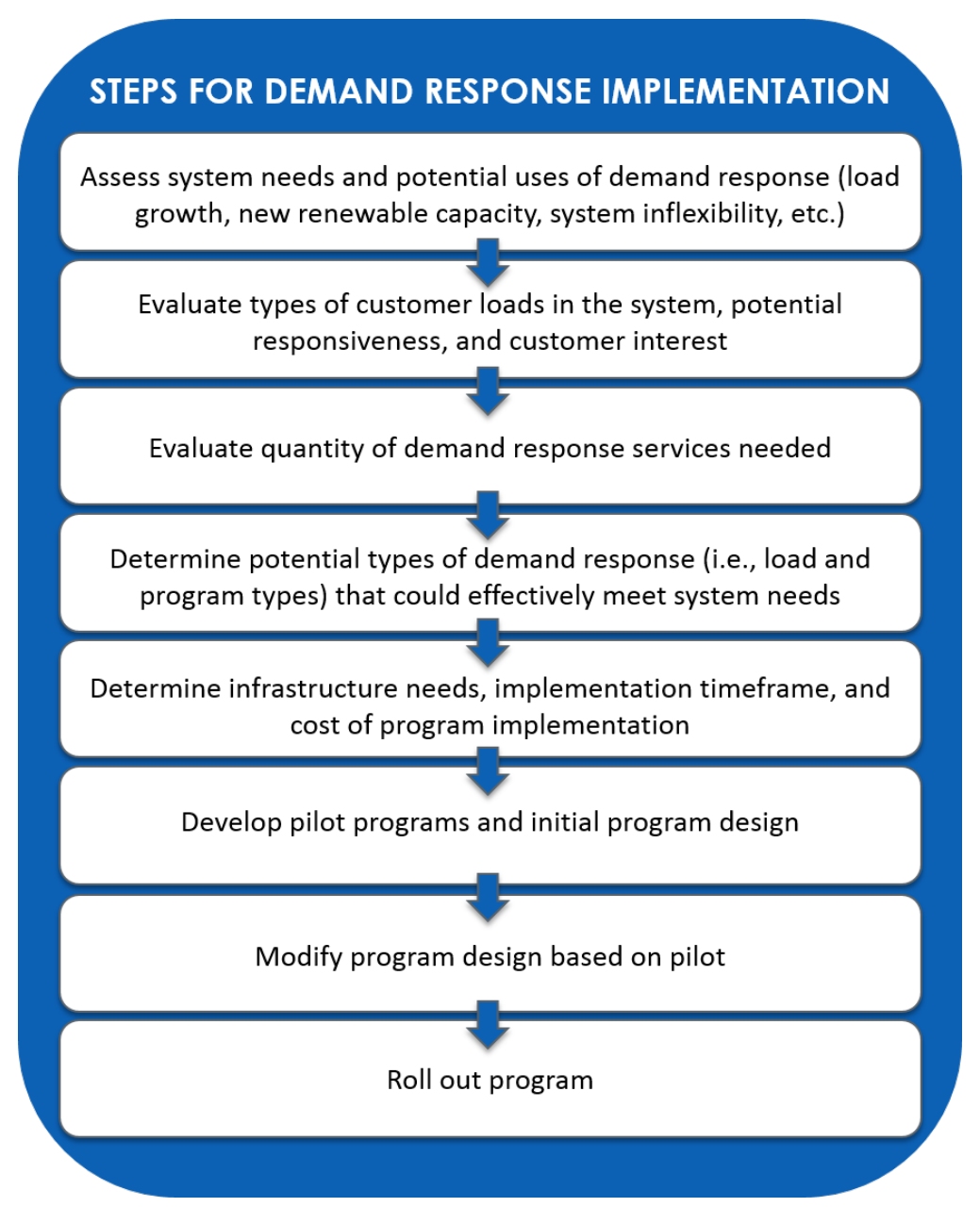

Figure 4. Template of the demand response planning process

Based on the characteristics of various demand response programs and power systems with high penetrations of wind and solar, the types of programs most likely to meet systems' needs for reliable responses under changing conditions include:

- Automated, incentive-based aggregation and direct load control programs

- Real-time prices, or other time-varying prices that are well aligned with system needs, for which the demand-side response is facilitated by automatic control

- Critical peak pricing programs.

Aggregation and direct load control are relatively well understood, reliable when done well, and can be tailored to fit a variety of needs. Real-time pricing programs coupled with automated controls hold promise but have yet to be fully proven, especially with regard to including pricedriven responses in the price formation process as is needed to produce reliable grid operations at high penetration. Critical peak pricing programs may be especially useful in the short term, as they can produce significant response at peak times with smaller infrastructure investments, especially for utilities already undertaking advanced metering initiatives. 


\section{Conclusions}

A variety of demand response program types have been used or piloted around the world. On the retail side, interruptible and curtailable tariffs were a common starting point, but they have given way to more robust demand response programs based on direct load control or pay-forperformance. Time-of-use rates are widely available options that do affect some load shifting and peak load reductions but not always as much as one would expect. Recently, other types of dynamic pricing, such as critical peak pricing and real-time pricing have been piloted or introduced as long-term options. Wholesale demand response programs are more recent, but are rapidly expanding to provide a variety of services in several markets.

Traditionally, and even today, demand response is most commonly used to provide capacity that counts toward planning reserves and long-term reliability, and the attendant reductions in load at times near system peak or in emergency conditions as required by such a resource. Demand response thus contributes to both long-term and short-term system reliability, and as a local resource, enhances energy security. Especially with the opening of wholesale markets to demand response, additional services, specifically economic energy shifting, regulation reserve signal following, and other active forms of load balancing are becoming more common in more places. These types of services typically provide additional economic value or cost savings to the system.

Electricity systems with high demand growth and clean energy goals may want to consider accelerating the development of demand response programs specifically tailored to providing additional reliability in the short to medium term, and the ability to help integrate variable generation in the medium to long term. To that end, modern, verifiable forms of emergency demand response from large commercial and industrial customers may be a natural place to start. Residential critical peak pricing programs can also be effective, and they do not require much communication infrastructure. Static ToU tariffs, which already have a mixed record as to how effective they are at shifting load away from peak times, are likely to become even less effective as additional variable generation makes net load curves less predictable and more correlated with weather rather than schedules. Instead, in preparation for deeper forms of demand response on the residential side, utilities and regulators may want to consider which types of appliances and other loads might be able to provide useful services in the future, and what the most effective means of tapping into those resources might be. Advanced metering might be desirable if real-time pricing plus automatic controllers are anticipated, or if the responses of third-party aggregators are to be verified through official meter readings. If other forms of control or verification are anticipated, for instance, direct load control of select appliances plus verification based on a sample of participants, or automatic control of programmable communicating thermostats, widespread investments in advanced meters may be unnecessary.

The ability of demand response to help integrate variable renewable generation has not yet been precisely quantified, but there are two general trends. First, the impact of demand response on emissions is highly system-dependent. For systems at low penetrations of wind and PV and with inexpensive, inflexible coal capacity available, the addition of demand response is likely to increase rather than decrease emissions to the extent that it reduces the operation of natural gas generators in favor of coal generators. However, this trend reverses once wind and PV 
penetrations increase far enough past the point of requiring system-balancing curtailments. In that case, demand response is used more to reduce renewable energy curtailment, which has a net impact on reducing emissions. Second, demand response can be used to provide regulation and other system balancing reserves that are needed at greater magnitudes as more wind and solar PV are added to the system. However, even in high wind and solar cases, system balancing needs are likely to stay in the range of a few to a dozen percentage points of load. This modest need combined with ancillary services generally being about an order of magnitude less expensive to provide than energy means demand response resources will typically be unable to justify themselves based solely on regulation and other balancing service revenue streams, especially with emerging technologies such as battery storage also competing to provide these services. For this reason, the role of demand response as a capacity resource is likely to remain important.

Future research should provide a better idea of which types of demand response are most valuable when and where. In the meantime, system operators everywhere can investigate how demand response programs might be able to provide additional reliability for their systems, with an eye toward programs that will be robust under swiftly changing net load patterns. 


\section{References}

AEMC. 2009. "Review of Demand-Side Participation in the National Electricity Market." Final Report. Sydney, Australia: Australian Energy Market Commission (AEMC).

http://www.aemc.gov.au/getattachment/c6c5860b-970b-43e7-9c8a-57cf9f4cf1d9/Stage-2-FinalReport.aspx.

Alliance to Save Energy. 2013. "The History of Energy Efficiency." Alliance to Save Energy, Alliance Commission on National Energy Efficiency Policy.

https://www.ase.org/sites/ase.org/files/resources/Media\%20browser/ee_commission_history_rep ort_2-1-13.pdf.

Badiani, Reena, Katrina K. Jessoe, and Suzanne Plant. 2012. "Development and the Environment: The Implications of Agricultural Electricity Subsidies in India." The Journal of Environment \& Development 21 (2): 244-62. https://doi.org/10.1177/1070496512442507.

Baker, Scott. 2016. "Energy Storage in PJM: Overview of Rules and Requirements." Presented at the Clean Energy States Alliance Webinar, February 23. http://www.cleanegroup.org/wpcontent/uploads/RPP-PJM-Webinar-Slides-2.23.16.pdf.

Barbose, Galen, Charles Goldman, and Bernie Neenan. 2004. "A Survey of Utility Experience with Real Time Pricing.” Technical Report LBNL-54238. Berkeley, California: Lawrence Berkeley National Laboratory (LBNL). https://eetd.lbl.gov/sites/all/files/publications/report-lbnl54238.pdf.

Barooah, Prabir, Ana Buic, and Sean Meyn. 2015. "Spectral Decomposition of Demand-Side Flexibility for Reliable Ancillary Services in a Smart Grid." In System Sciences (HICSS), 2015 48th Hawaii International Conference On, 2700-2709. IEEE.

http://ieeexplore.ieee.org/xpls/abs_all.jsp?arnumber=7070140.

Beijing Finance Bureau, Beijing Development and Reform Commission. 2013. "Beijing Electric Demand Side Management City Pilot Finance Reward Fund Management Method." Beijing.

Bhatnagar, R., and S. Rahman. 1986. "Dispatch of Direct Load Control for Fuel Cost Minimization." IEEE Transactions on Power Systems 1 (4): 96-102. https://doi.org/10.1109/TPWRS.1986.4335023.

Bloom, Aaron, Aaron Townsend, David Palchak, Joshua Novacheck, Jack King, Clayton Barrows, Eduardo Ibanez, et al. 2016. "Eastern Renewable Generation Integration Study." NREL/TP-6A20-64472. Golden, CO: NREL. http://www.nrel.gov/docs/fy16osti/64472.pdf.

BMW Group, and Pacific Gas and Electric Company. 2017. "BMW i ChargeForward: PG\&E's Electric Vehicle Smart Charging Pilot.” PG\&E Currents. http://www.pgecurrents.com/wpcontent/uploads/2017/06/PGE-BMW-iChargeForward-Final-Report.pdf.

Borenstein, Severin. 2005. "The Long-Run Efficiency of Real-Time Electricity Pricing.” The Energy Journal, 93-116. 
Brinkman, G., J. Jorgenson, J. Caldwell, and A. Ehlen. 2015. "Low Carbon Grid Study: Analysis of a 50\% Emission Reduction in California." Technical Report NREL/TP-6A20-64884. Golden, Colorado: National Renewable Energy Laboratory (NREL).

Cappers, Peter, Charles Goldman, and David Kathan. 2010. "Demand Response in U.S. Electricity Markets: Empirical Evidence." Energy, Demand Response Resources: the US and International ExperienceDemand Response Resources: the US and International Experience, 35 (4): 1526-35. https://doi.org/10.1016/j.energy.2009.06.029.

Cappers, Peter, Andrew Mills, Charles Goldman, Ryan Wiser, and Joseph Eto. 2011. "Mass Market Demand Response and Variable Generation Integration Issues: A Scoping Study." Technical Report LBNL-5063E. Berkeley, California: Lawrence Berkeley National Laboratory (LBNL). https://emp.lbl.gov/sites/default/files/lbnl-5063e.pdf.

Central Electricity Authority. 2016. "Load Generation Balance Report 2016-17.” New Delhi, India: Central Electricity Authority, India. http://www.cea.nic.in/reports/annual//gbr/lgbr2016.pdf.

Commonwealth Edison Company. 2017. Hourly Pricing. 2017. https://hourlypricing.comed.com/about/.

Comverge. 2014. "Utility Cast Study: Eskom South African Power Utility, Demand Response Pilot Delivers 15,260 MWh of Load Reduciton in Seven Months." Whitepaper. http://www.comverge.com/Comverge/media/pdf/Case\%20Studies/Eskom-Case-Study.pdf.

CPUC. 2015. "Approval with Modifications to the Joint Utility Proposal for a Demand Response Auction Mechanism Pilot." California: California Public Utilities Commission (CPUC). http://docs.cpuc.ca.gov/PublishedDocs/Published/G000/M153/K436/153436367.pdf.

—. 2016. "CPUC Approves Pilot Program for Special Mid-Day Rates for Edison and SDG\&E Commercial Customers." Press Release. San Francisco, California: California Public Utilities Commission (CPUC). http://docs.cpuc.ca.gov/PublishedDocs/Published/G000/M169/K866/169866724.PDF.

Crossley, David. 2011. "Demand-Side Participation in the Australian National Electricity Market." Technical Report. Montpelier, Vermont: The Regulatory Assistance Project. http://www.efa.com.au/Library/David/Published\%20Reports/2011/RAP_Crossley_DSParticipati onAustralianNatlElectricityMkt.pdf.

Curtis, Mitchell. 2015. "Overview of the UK Demand Response Market." Presented at the EPFL Workshop, September 11. http://www.irgc.org/wp-content/uploads/2015/09/Curtis-DemandResponse-2015.pdf.

Denholm, P., J. Jorgenson, M. Hummon, D. Palchak, B. Kirby, O. Ma, and M. O’Malley. 2013. "Impact of Wind and Solar on the Value of Energy Storage." Technical Report NREL/TP-6A2060568. Golden, Colorado: National Renewable Energy Laboratory (NREL). http://www.nrel.gov/docs/fy14osti/60568.pdf. 
Denholm, Paul, and Robert Margolis. 2016. "Energy Storage Requirements for Achieving 50\% Penetration of Solar Photovoltaic Energy in California." Technical Report NREL/TP-6A2066595. Golden, Colorado: National Renewable Energy Laboratory (NREL). http://www.nrel.gov/docs/fy16osti/66595.pdf.

Denholm, Paul, Joshua Novacheck, Jennie Jorgenson, and Matthew O'Connell. 2016. "Impact of Flexibility Options on Grid Economic Carrying Capacity of Solar and Wind: Three Case Studies.” Technical Report NREL/TP-6A20-66854. Golden, Colorado: National Renewable Energy Laboratory. http://www.nrel.gov/docs/fy17osti/66854.pdf.

Dong, Jun, Guiyuan Xue, and Rong Li. 2016. "Demand Response in China: Regulations, Pilot Projects and Recommendations - A Review." Elsevier Renewable and Sustainable Energy Reviews 50: 13-27.

Dupuy, Max. 2016. “China Power Sector Reform: Key Issues for the World's Largest Power Sector.” Beijing, China: The Regulatory Assistance Project. http://www.raponline.org/wpcontent/uploads/2016/07/rap-dupuy-key-issues-china-power-sector-2016-march.pdf.

Eberhard, Anton, Joel Kolker, and James Leigland. 2014. "South Africa's Renewable Energy IPP Procurement Program: Success Factors and Lessons." Public-Private Infrastructure Advisory Facility (PPIAF), World Bank Group. http://www.gsb.uct.ac.za/files/ppiafreport.pdf.

Electric Light \& Power. 2008. "EnerNOC to Roll Existing ISO New England Capacity into New Contract with CL\&P," March 4, 2008. http://www.elp.com/articles/2008/03/enernoc-to-rollexisting-iso-new-england-capacity-into-new-contract-with-clp.html.

EPRI. 2012. "Understanding Electric Utility Customers -- Summary Report: What We Know and What We Need to Know." Technical Report 1025856. Electric Power Research Institute (EPRI). https://www.epri.com/\#/pages/product/000000000001025856/.

ERCOT. 2006. "Load Participation in the ERCOT Market: Financial Opportunities for Reducing Electricity Load, An Introduction to ERCOT's Load Reduction Programs and the ERCOT Protocols." Prepared by the Demand-Side Working Group of the ERCOT Wholesale Market Subcommittee. Electric Reliability Council of Texas (ERCOT). http://www.ercot.com/services/programs/load/Load\%20Participation\%20in\%20the\%20ERCOT \%20Market\%20May\%202006.doc.

—. 2017. "2016 Annual Report of Demand Response in the ERCOT Region." Electric Reliability Council of Texas (ERCOT).

http://mis.ercot.com/misapp/GetReports.do?reportTypeId=13244\&reportTitle=Annual\%20Repor t\%20on\%20ERCOT\%20Demand\%20Response\&showHTMLView=\&mimicKey.

Eskom. 2017. "Eskom Is Now Delivering Excess Electricity Capacity to Power SA's Economic Growth." Press Release, January 24, 2017. http://www.eskom.co.za/news/Pages/Jann24.aspx.

Faruqui, Ahmad, and Sanem Sergici. 2010. "Household Response to Dynamic Pricing of Electricity: A Survey of 15 Experiments." Journal of Regulatory Economics 38 (2): 193-225. https://doi.org/10.1007/s11149-010-9127-y. 
- 2011. "Dynamic Pricing of Electricity in the Mid-Atlantic Region: Econometric Results from the Baltimore Gas and Electric Company Experiment." Journal of Regulatory Economics 40 (1): 82-109.

Faruqui, Ahmad, Sanem Sergici, and Ahmed Sharif. 2010. "The Impact of Informational Feedback on Energy Consumption-A Survey of the Experimental Evidence." Energy, Demand Response Resources: the US and International Experience, 35 (4): 1598-1608. https://doi.org/10.1016/j.energy.2009.07.042.

Feldman, Brett, and Bob Lockhart. 2014. "Demand Response: Commercial \& Industrial DR, Residential DR, and DR Management Systems: Global Market Analysis and Forecasts." Navigant Research.

FERC, The Brattle Group, Freeman Sullivan, and Global Energy Partners. 2009. "A National Assessment of Demand Response Potential." Federal Energy and Regulatory Commission (FERC), prepared by The Brattle Group, Freeman Sullivan \& Co, and Global Energy Partners.

Foshan Economic Information Committee, Foshan City Electric Demand Side Management City Pilot Leading Group Office. 2015. "Notification of the Application for the Foshan Electric Demand Response Pilot Project.” Guangdong, Foshan.

FPL. 2016. "Ten Year Power Plant Site Plan 2016-2025.” Submitted to the Florida Public Service Commission. Florida Power \& Light (FPL). https://www.fpl.com/company/pdf/10-yearsite-plan.pdf.

FPSC. 2015. "Docket No. 150085-EG — Petition for Approval of Florida Power \& Light Company's Demand-Side Management Plan and Request to Cancel Closed on Call Tariff Sheets." Memorandum Document No. 04296-15. Tallahassee, Florida: State of Florida Public Service Commission (FPSC). http://www.psc.state.fl.us/library/filings/15/04296-15/0429615.pdf.

Fryer, Lynn, Steven Schiller, Andrea Geanacopoulos, and Harlan Coomes. 2002. "Demand Responsive Load Management: From Programs to a Demand Response Market." In ACEEE Summer Study Proceedings.

Ghatikar, Girish, Rongxin Yin, Ranjit Deshmukh, and G. Ganesh Das. 2015. "Characterization and Effectivenss of Technologies for India's Electric Grid Reliability and Energy Security." Conference Paper LBNL-6994E. Presented at the India Smart Grid Week (ISGW) 2015: Lawrence Berkeley National Laboratory (LBNL). https://www.researchgate.net/profile/Rish_Ghatikar/publication/275643843_Characterization_an d_Effectiveness_of_Technologies_for_India's_Electric_Grid_Reliability_and_Energy_Security/1 inks/554196980cf2322227316fa2.pdf.

Gils, Hans Christian. 2014. "Assessment of the Theoretical Demand Response Potential in Europe." Energy 67: 1-18.

gtmresearch. 2017. “Grid Edge Quarterly Executive Briefing — Q2 2017.” gtmresearch. 
Hale, Elaine T., Brady L. Stoll, and Joshua E. Novacheck. 2018. "Integrating Solar into Florida's Power System: Potential Roles for Flexibility.” Solar Energy 170 (August): 741-51. https://doi.org/10.1016/j.solener.2018.05.045.

Harbaugh, Wayne. 2015. “BGE's Residential Smart Energy Rewards (SER) Program.” Presented at the NY REV: The Role of Time-Variant Pricing Forum, March 31.

https://www.edf.org/sites/default/files/content/harbaugh_presentation.pdf.

Heffner, Grayson, Chuck Goldman, Brendan J. Kirby, and Michael Kintner-Meyer. 2007. "Loads Providing Ancillary Services: Review of International Experience." Technical Report LBNL-62701, ORNL/TM-2007/060, PNNL-16618. Berkeley, California: Lawrence Berkeley National Laboratory (LBNL). https://www.osti.gov/scitech/servlets/purl/970866.

Hummon, M. R., P. Denholm, J. Jorgenson, D. Palchak, B. Kirby, O. Ma, and Washington U. S. Department of Energy. 2013. "Fundamental Drivers of the Cost and Price of Operating Reserves." Technical Report NREL/TP-6A20-58491. Golden, Colorado: National Renewable Energy Laboratory (NREL). http://www.nrel.gov/docs/fy13osti/58491.pdf.

Hummon, Marissa, David Palchak, Paul Denholm, Jennie Jorgenson, Daniel J. Olsen, Sila Kiliccote, Nance Matson, et al. 2013. "Grid Integration of Aggregated Demand Response, Part 2: Modeling Demand Response in a Production Cost Model." Technical Report NREL/TP-6A2058492. Golden, Colorado: National Renewable Energy Laboratory (NREL). http://www.nrel.gov/docs/fy14osti/58492.pdf.

Hurley, Doug, Paul Peterson, and Melissa Whited. 2013. "Demand Response as a Power System Resource-Program Designs, Performance, and Lessons Learned in the United States." Synapse Energy Economics Inc. http://www.synapse-energy.com/sites/default/files/SynapseReport.201303.RAP_.US-Demand-Response.12-080.pdf.

IEA. 2017. "China's Energy Supply and Consumption Revolution Strategy (2016-2030)." Database. International Energy Agency (IEA) Policies and Measures Database. 2017. https://www.iea.org/policiesandmeasures/pams/china/name-162879en.php?s=dHlwZT1jYyZzdGF0dXM9T2s,\&return=PG5hdiBpZD0iYnJlYWRjenVtYiIPGEgaHJIZj0iLyISG9tZTwvYT4gJnJhcXVvOyA8YSBocmVmPSIvcG9saWNpZXNhbmRtZWFzdXJlcy8iPIBvb GljaWVzIGFuZCBNZWFzdXJlczwvYT4gJnJhcXVvOyA8YSBocmVmPSIvcG9saWNpZXNhb mRtZWFzdXJlcy9jbGltYXR1Y2hhbmdlLyI-Q2xpbWF0ZSBDaGFuZ2U8L2E-PC9uYXY-.

Indo-German Energy Programme. 2015. "Report on Market Design for Capacity Market in India.” Deutsche Gesellschaft für Internationale Zusammenarbeit GmbH. 
ISO-NE. 2004. "ISO New England/NEPOOL Demand Response Working Group Meeting." Presented at the Demand Response Department, ISO New England, Inc., Holyoke, Massachusetts, January 7.

https:/www.google.com/url?sa $=$ t\&rct=j\&q=\&esrc $=$ s\&source=web\&cd=4\&cad=rja\&uact $=8 \& v e$ $\mathrm{d}=$ 0ahUKEwiDreG71ZPWAhXEjVQKHe9dAtoQFgg5MAM\&url=https\%3A\%2F\%2Fwww.isone.com $\% 2$ Fstatic-

assets $\% 2 \mathrm{Fdocuments} \% 2 \mathrm{Fcommittees} \% 2 \mathrm{Fcomm}$ _wkgrps $\% 2 \mathrm{Fmrkts}$ comm $\% 2 \mathrm{Fdr}$ wkgrp $\% 2 \mathrm{Fmt}$ rls\%2F2004\%2Fjan72004\%2FDR_Working_Group_Meeting_01_01_2004_hyy.ppt\&usg=AFQj CNEK94-1GEcng6dedpNP4jVEO-xOnA.

ISO-NE IMM. 2017. “ISO New England's Internal Market Monitor 2016 Annual Markets Report.” ISO New England Inc., Internal Market Monitor (ISO-NE IMM). https://www.isone.com/static-assets/documents/2017/05/annual_markets_report_2016.pdf.

Jessoe, Katrina, and David Rapson. 2015. "Commercial and Industrial Demand Response Under Mandatory Time-of-Use Electricity Pricing." The Journal of Industrial Economics 63 (3): $397-$ 421.

Komives, Kristin, Vivien Foster, Johnathan Halpern, and Quentin Wodon. 2005. Water, Electricity, and the Poor: Who Benefits from Utility Subsidies? Directions in Development 34334. World Bank Publications.

https://books.google.com/books?hl=en\&lr=\&id=cE9RJeJNzsQC\&oi=fnd\&pg=PR13\&dq=water + electricity+and+the+poor\&ots=WwKM-UwITJ\&sig=HACzDVde-jvYCmsfsObBTljo1FA.

Lee, Michael P., Ben Foster, David Kathan, Meghan O’Brien, April Park, and Samin Peirovi. 2016. "Assessment of Demand Response and Advanced Metering." Staff Report. Federal Energy Regulatory Commission (FERC). https://www.ferc.gov/legal/staff-reports/2016/DR-AMReport2016.pdf.

Lin, Jiang, Xu Liu, and Fredrich Karl. 2016. “Excess Capacity in China’s Power Systems: A Regional Analysis.” Technical Report LBNL-1006638. Berkeley, California: Lawrence Berkeley National Laboratory (LBNL). https://eta.lbl.gov/sites/all/files/publications/lbnl1006638.pdf.

Liu, Yingqi, Nick Eyre, Sarah Darby, Malcolm Keay, David Robinson, and Xin Li. 2015. "Assessment of Demand Response Market Potential and Benefits in Shanghai." Technical Report. Beijing, China: Environmental Change Institute and Oxford Institute for Energy Studies, Prepared for the National Resources Defense Council (NRDC).

https://www.nrdc.org/sites/default/files/assessment-

demandresponsepotentialbenefitsshanghai.pdf.

Lyons, Cristin, and Vazken Kassakhlan. 2016. "Distributed Energy Resources Integration: Policy, Technical, and Regulatory Perspectives from New York and California." 51st State Perspectives. The 51st State.

Ma, Ookie, Kerry Cheung, Daniel J. Olsen, Nance Matson, Michael D. Sohn, Cody M. Rose, Junqiao Han Dudley, et al. 2016. "Demand Response and Energy Storage Integration Study." Technical Report DOE-EE-1282. U.S. Department of Energy. http://energy.gov/sites/prod/files/2016/03/f30/DOE-EE-1282.pdf. 
Maggiore, Simone, Massimo Gallanti, Walter Grattieri, and Michele Benini. 2013. "Impact of the Enforcement of a Time-of-Use Tariff to Residential Customers in Italy." In Electricity Distribution (CIRED 2013). Stockholm.

http://ieeexplore.ieee.org/stamp/stamp.jsp?tp=\&arnumber=6683276\&isnumber=6683125.

McAnany, James. 2016. "2015 Demand Response Operations Markets Activity Report: May 2016.” PJM Demand Side Response Operations. https://www.pjm.com/ /media/marketsops/dsr/2015-demand-response-activity-report.ashx.

— . 2017. "2016 Demand Response Operations Markets Activity Report: January 2017." PJM Demand Side Response Operations. https://www.pjm.com/ /media/markets-ops/dsr/2015demand-response-activity-report.ashx.

Milligan, Michael, Pearl Donohoo, Debra Lew, Erik Ela, Brendan Kirby, Hannele Holttinen, Eamonn Lannoye, et al. 2010. "Operating Reserves and Wind Power Integration: An International Comparison." In Proc. 9th International Workshop on Large-Scale Integration of Wind Power into Power Systems, 18-29.

https://pdfs.semanticscholar.org/f711/c2566ac1b146ebfb91f11764519b710320d7.pdf.

Mills, Andrew, and Joachim Seel. 2015. "Flexibility Inventory for Western Resource Planners." Technical Report LBNL-1003750. Berkeley, California: Lawrence Berkeley National Laboratory (LBNL). https://emp.lbl.gov/sites/all/files/lbnl-1003750_0.pdf.

Murtaugh, Gabe, Eric Hildebrandt, Ryan Kurlinski, Roger Avalos, Amelia Blanke, Mike Castelhano, Amol Deshmukh, et al. 2017. "2016 Annual Report on Market Issues \& Performance." California ISO.

http://www.caiso.com/Documents/2016AnnualReportonMarketIssuesandPerformance.pdf.

National Grid. 2015. "Final Auction Results: T-4 Capacity Market Auction for 2019/20." UK: National Grid UK. https://www.emrdeliverybody.com/Capacity\%20Markets\%20Document\%20Library/T4\%20Final\%20Results\%202015.pdf.

Navigant. 2013. "ADR Pilot Could Lead to Broad Deployments in China." Navigant Research (blog). July 8, 2013. https://www.navigantresearch.com/blog/adr-pilot-could-lead-to-broaddeployments-in-china.

Newbery, David, and Anton Eberhard. 2008. "South African Network Infrastructure Review: Electricity." Technical Report. National Treasury and the Department of Public Enterprises, Government of South Africa. http://www.gsb.uct.ac.za/files/saelectricitypaper08.pdf.

NYISO. 2017. "NYISO 2016 Annual Report on Demand Response Programs." New York Independent System Operator (NYISO).

http://www.nyiso.com/public/webdocs/markets_operations/market_data/demand_response/Dema nd_Response/Reports_to_FERC/2017/NYISO\%202016\%20Annual\%20Report\%20on\%20Dema nd\%20Response\%20Programs_Final.pdf. 
NYPSC. 2016. "Order Adopting a Ratemaking and Utility Revenue Model Policy Framework." New York: New York Public Service Commission.

http://documents.dps.ny.gov/public/Common/ViewDoc.aspx?DocRefId=\{D6EC8F0B-61414A82-A857-B79CF0A71BF0\}.

Olsen, Daniel J., Nance Matson, Michael D. Sohn, Cody Rose, Junqiao Dudley, Sasank Goli, Sila Kiliccote, et al. 2013. "Grid Integration of Aggregated Demand Response, Part 1: Load Availability Profiles and Constraints for the Western Interconnection." Technical Report LBNL6417E. Berkeley, California: Lawrence Berkeley National Laboratory (LBNL). http://eetd.lbl.gov/sites/all/files/lbnl-6417e.pdf.

Pacific Gas and Electric Company. 2016. "PG\&E and BMW Partner on Next Phase of Pilot Studying Advanced Electric Vehicle Charging." News Releases. November 14, 2016. https://www.pge.com/en/about/newsroom/newsdetails/index.page?title=20161114_pge_and_bm w_partner_on_next_phase_of_pilot_studying_advanced_electric_vehicle_charging_.

Patton, David B., Pallas LeeVanSchaick, and Jie Chen. 2017. "2016 State of the Market Report for the New York ISO Markets." Potomac Economics, Ltd., Market Monitoring Unit for the New York ISO.

http://www.nyiso.com/public/webdocs/markets_operations/documents/Studies_and_Reports/Rep orts/Market_Monitoring_Unit_Reports/2016/NYISO_2016_SOM_Report_5-10-2017.pdf.

Pigeon, James. 2017. "Distributed Energy Resource Aggregations." Presented at the Market Issues Working Group (MIWG), NYISO, Rensselaer, NY, February 28.

http://www.nyiso.com/public/webdocs/markets_operations/committees/bic_miwg/meeting_mate rials/2017-02-

28/Distributed\%20Energy\%20Resource\%20Aggregations\%20MIWG\%20022817.pdf.

PJM. 2017. "Demand Response.” http://learn.pjm.com/three-priorities/buying-and-sellingenergy/markets-faqs/ /media/BD49AF2D60314BECA9FAAB4026E12B1A.ashx.

Pollitt, Michael G., Chung-Han Yang, and Hao Chen. 2017. "Reforming the Chinese Electricity Supply Sector: Lessons from International Experience.” EPRG Working Paper 1704; Cambridge Working Paper in Economics 1713. University of Cambridge, Energy Policy Research Group. http://www.eprg.group.cam.ac.uk/wp-content/uploads/2017/03/1704-Text.pdf.

Poojary, Rajesh V., Girish Ghatikar, G. Ganesh Das, and Sujay Kumar Saha. 2015. “Open Automated Demand Response: Industry Value to Indian Utilities and Knowledge from the Deployment." Conference Paper LBNL 6986E. Presented at the India Smart Grid Week (ISGW) 2015: Lawrence Berkeley National Laboratory (LBNL). https://eetd.lbl.gov/sites/all/files/lbnl_6986e.pdf.

Potomac Economics. 2016. "2015 State of the Market Report for the ERCOT Wholesale Electricity Markets.” Independent Market Monitor Report. Potomac Economics, Ltd. https://www.potomaceconomics.com/uploads/ercot_documents/2015_ERCOT_State_of_the_Ma rket_Report.pdf. 
2017. "2016 State of the Market Report for the MISO Electricity Markets." Potomac Economics, Ltd., Independent Market Monitor for the Midcontinent ISO (MISO). https://www.misoenergy.org/Library/Repository/Report/IMM/2016\%20State\%20of\%20the\%20 Market\%20Report.pdf.

REN21. 2017. "Renewables 2017 Global Status Report.” Paris, France: REN21: Renewable Energy Policy Network for the 21st Century. http://www.ren21.net/wpcontent/uploads/2017/06/17-8399_GSR_2017_Full_Report_0621_Opt.pdf.

Ritter, Fred. 2011. "Underfrequency Load Shedding - Alberta Interconnected Electric System." Presented at the APIC Technical Forum, University of Alberta-Edmonton, November 3. http://www.ece.ualberta.ca/ apic/uploads/Forum/Underfrequency\%20Load\%20Shedding.pdf.

Roozbehani, M., M. Dahleh, and S. Mitter. 2010. "On the Stability of Wholesale Electricity Markets under Real-Time Pricing." In 49th IEEE Conference on Decision and Control (CDC), 1911-18. https://doi.org/10.1109/CDC.2010.5718173.

Roscoe, A. J., and G. Ault. 2010. "Supporting High Penetrations of Renewable Generation via Implementation of Real-Time Electricity Pricing and Demand Response." IET Renewable Power Generation 4 (4): 369-82. https://doi.org/10.1049/iet-rpg.2009.0212.

RTE France. 2014. "GENERATION ADEQUACY REPORT on the Electricity Supply-Demand Balance in France." RTE France. http://www.rtefrance.com/sites/default/files/2014_11_18_generation_adequacy_report_executive_summary.pdf.

Samad, T., E. Koch, and P. Stluka. 2016. "Automated Demand Response for Smart Buildings and Microgrids: The State of the Practice and Research Challenges." Proceedings of the IEEE 104 (4): 726-44. https://doi.org/10.1109/JPROC.2016.2520639.

SEDC. 2015. "Mapping Demand Response in Europe Today.” Smart Energy Demand Coalition (SEDC). http://www.smartenergydemand.eu/wp-content/uploads/2015/09/Mapping-DemandResponse-in-Europe-Today-2015.pdf.

Singh, Rajesh Kumar. 2017. "Modi Will Spend \$2.5 Billion on Pledge to Electrify Every Home." Bloomberg.Com, September 25, 2017. https://www.bloomberg.com/news/articles/201709-25/india-s-modi-starts-2-5-billion-plan-to-grow-electricity-access.

Songsong, Chen. 2017. "Research Frontiers and Development Dynamics of Demand Response under Deregulated Electric Power Retail Market." Presented at the 17th IERE General Meeting and Canada Forum: Electric power storage, energy conversion and impact on the 21 st century power grid, Vancouver, Canada, May. https://www.iere.jp/events/forum/2017-canada/Presen/S37.pdf.

Spees, Kathleen, and Samuel Newell. 2014. "Resource Adequancy in Western Australia: Alternatives to the Reserve Capacity Mechanism." The Brattle Group. http://www.brattle.com/system/publications/pdfs/000/005/070/original/WA_Resource_Adequacy _Spees_Newell.pdf?1408985223. 
St. John, Jeff. 2016. "California's DRAM Auction Contracts for 82MW of Distributed Energy as Grid Resource," August 3, 2016. https://www.greentechmedia.com/articles/read/californiasdram-auction-Contracts-for-82mw-of-distributed-energy-as-grid-r.

Star, Anthony, Marjorie Isaacson, and Larry Kotewa. 2014. "Evaluating Residential Real-Time Pricing: Connecting Customer Response to Energy Market Impacts."

http://www.elevateenergy.org/wp/wpcontent/uploads/2014/01/Evaluating_Residential_Real_Time_Pricing.pdf.

Stern, Florian. 2015. "DEMAND RESPONSE IN CHINA- The Market \& Strategic Positioning of Active Players." Azure International. http://www.azureinternational.com/images/stories/azure/publications/pdf/DEMAND-RESPONSE-INCHINA_The-Market-Strategic-Positioning-of-Active-Players_2015_Azure-International_FS.pdf.

Suzhou City Electric Demand Side Management City Pilot Leading Group Office. 2015. "Notice on Improving Optimization of Electricity and Electricity Demand Response Management Program in Suzhou." Jiangsu, Suzhou.

Tangshan Finance Bureau, Tangshan City Bureau of Industry and Information Technology. 2013. "Tangshan City Special Fund Management Approach for Demand Side Management City Pilot Project (Trial)." Hebei, Tangshan.

THEMA Consulting Group. 2015. "Capacity Adequacy in the Nordic Electricity Market." Technical Report. Copenhagen, Denmark: Nordic Council of Ministers. http:/www.nordicenergy.org/wp-content/uploads/2015/08/capacity_adequacy_THEMA_20151.pdf.

Torriti, Jacopo. 2012. "Price-Based Demand Side Management: Assessing the Impacts of Timeof-Use Tariffs on Residential Electricity Demand and Peak Shifting in Northern Italy." Energy, Integration and Energy System Engineering, European Symposium on Computer-Aided Process Engineering 2011, 44 (1): 576-83. https://doi.org/10.1016/j.energy.2012.05.043.

U.S. EIA. 2016. "Monthly Energy Review.” U.S. Energy Information Administration. http://www.eia.gov/totalenergy/data/monthly/\#electricity.

Yung, Brian. 2017. "DER Pilot Program.” Presented at the Market Issues Working Group (MIWG), NYISO, Rensselaer, NY, September 29.

http://www.nyiso.com/public/webdocs/markets_operations/committees/bic_miwg/meeting_mate rials/2017-09-29/7\%20DER\%20Pilot\%20Program\%20MIWG\%20092917.pdf.

Zarnikau, Jay W. 2010. "Demand Participation in the Restructured Electric Reliability Council of Texas Market.” Energy 35 (4): 1536-1543.

Zhao, Zhijun, Can Yu, Mona Yew, and Mingming Liu. 2015. "Demand Side Management: A Green Way to Power Beijing.” Journal of Renewable and Sustainable Energy 7 (4): 041505. 